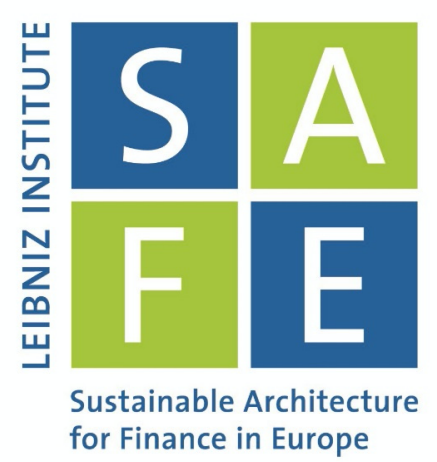

Alperen A. Gözlügöl

\title{
The Clash of 'E' and 'S' of ESG: Just Transition on the Path to Net Zero and the Implications for Sustainable Corporate Governance and Finance
}

SAFE Working Paper No. 325

\section{Leibniz Institute for Financial Research SAFE}

Sustainable Architecture for Finance in Europe 


\section{The Clash of 'E' and 'S' of ESG: Just Transition on the Path to Net Zero and the Implications for Sustainable Corporate Governance and Finance}

Alperen A. Gözlügöl 


\title{
THE CLASH OF 'E' AND 'S' OF ESG: JUST TRANSITION ON THE PATH TO NET ZERO AND THE IMPLICATIONS FOR SUSTAINABLE CORPORATE GOVERNANCE AND FINANCE
}

\author{
Alperen A. Gözlügöl* \\ First version: 08.11.2021
}

\begin{abstract}
Climate change is one of the highest-ranking issues on the political and social agenda. Vulnerabilities of the world ecosystem laid bare by the COVID-19 pandemic and the potential damage for the human and business life made the need for urgent action clear once again. Corporations are one of the main actors that will play a major role in the decarbonisation of the economy. They need to put forward a net zero strategy and targets, transitioning to net-zero by 2050. Yet, an important but rather overlooked stakeholder group in the sustainability debates can pose a significant stumbling block in this transition: employees. Although climate action has huge benefits by ameliorating adverse environmental events and is expected to have overall positive impact on employment, net zero transition in companies, especially in certain sectors and regions, will cause substantial adverse employment effects for the workforce. This has the potential to slow down or even derail the necessary climate action in companies. In this regard, just transition is a promising concept, which calls for a swift and decisive climate action in corporations while taking account of and mitigating adverse effects for their workforce. If well implemented, it can accelerate net zero transition in companies. This potential clash of environmental (E) and social (S) aspects of ESG agenda, materialised in the companies' net zero transition, and its potential remedy, just transition, have important implications for corporate governance and finance, especially for directors' duties \& executive remuneration, sustainability disclosures, institutional investors' engagement and green finance.
\end{abstract}

Keywords: climate change, sustainability, ESG, employees, workforce, net zero transition, corporate governance, institutional investors, green finance.

\section{Introduction}

While the world community is still recovering from the COVID-19 crisis, a more existential crisis looms large: climate change. Due to accumulating greenhouse gas emissions since the advent of industrial age, the planet earth expects increasing temperatures and accompanying

\footnotetext{
* Assistant Professor in the Law \& Finance Cluster of the Leibniz Institute for Financial Research SAFE. Comments are welcome to gozlugol@safe-frankfurt.de. The paper has benefited significantly from my fellow visit at the Center for Advanced Studies Foundations of Law and Finance funded by the German Research Foundation (Deutsche Forschungsgemeinschaft, DFG) - project FOR 2774. I also gratefully acknowledge research support from the Leibniz Institute for Financial Research SAFE. For valuable comments, I thank Sebastian Steuer.
} 
extreme weather events (such as intense droughts, hurricanes and rainfalls) that will happen in more places and more frequently. ${ }^{1}$ Unless decisive and swift actions are taken on various levels by several actors, climate change is on its path to become an existential threat for the humankind - a terminology used by the United Nations Secretary-General. ${ }^{2}$ While the necessity of climate action is long known and moderate steps in this direction have been taken, ${ }^{3}$ recently, the need for a more substantial response including significantly reducing greenhouse gas ('GHG') emissions has become high-ranking on the social and political agenda. An important milestone is the Paris Agreement where 196 Parties agreed to take action in order to limit global warming to tolerable levels, namely well below 2, preferably to 1.5 degrees Celsius, compared to pre-industrial levels. ${ }^{4}$ To attain this target, global emissions need to be halved by 2030 s and reach net zero by $2050 .^{5}$

Corporations are one of the main contributors to climate change as they imposed significant externalities on the environment and have become main GHG emitters. ${ }^{6}$ Without achieving sustainability in corporations and their transition in line with the net zero carbon goals, it will not be possible to keep global warming in check. Therefore, corporations are under increasing spotlight from various stakeholders, investors, regulators, and lawmakers to reduce their GHG emissions, and monitor and manage climate-related risks to their businesses.

In this line, measures and further reform options to put companies on a more environmentally sustainable path and to accelerate their net zero transition abound. For example, in the EU, the European Commission is deliberating to reform directors' duties to require them to "take into account all stakeholders' interests which are relevant for the long-term sustainability of the

\footnotetext{
${ }^{1}$ See, e.g., the latest report from the Intergovernmental Panel on Climate Change ('IPCC'), a United Nations body for assessing the science related to climate change. IPCC, 'Climate Change 2021: The Physical Science Basis, Summary for Policymakers' (Aug. 2021), available at https://www.ipcc.ch/report/ar6/wg1/downloads/report/IPCC_AR6_WGI_SPM.pdf.

${ }^{2}$ See https://news.un.org/en/story/2018/05/1009782, last accessed Sept. 21, 2021.

${ }^{3}$ For a summary, see Lisa Benjamin, Companies and Climate Change: Theory and Law in The United Kingdom (CUP 2021), pp. 80-90.

${ }^{4}$ On the Paris Agreement, see https://unfccc.int/process-and-meetings/the-paris-agreement/the-paris-agreement, last accessed Sept. 21, 2021.

${ }^{5}$ See, e.g., IPCC, 'Special Report: Global Warming of $1.5^{\circ} \mathrm{C}$, Summary for Policymakers' (2018), p. 12, available at https://www.ipcc.ch/site/assets/uploads/sites/2/2019/05/SR15_SPM_version_report_LR.pdf. Net zero means that any remaining emissions are offset by the total of active removals of GHG from the atmosphere.

${ }^{6}$ See, e.g., Richard Heede, Tracing Anthropogenic Carbon Dioxide And Methane Emissions To Fossil Fuel and Cement Producers, 1854-2010, (2014) 122 Climatic Change 229 (tracing 63\% of cumulative worldwide greenhouse gas emissions to the 90 'carbon major' entities); Carbon Disclosure Project, 'Carbon Majors Report 2017' (Jul. 2017), https://www.cdp.net/en/articles/media/new-report-shows-just-100-companies-are-source-ofover-70-of-emissions (linking 'carbon majors' to $71 \%$ of industrial greenhouse gas emissions since 1988).
} 
firm"7 rather than solely serving shareholders' interests, which have been argued to cause significant externalities for the environment. ${ }^{8}$ In addition, the proposal of a new Corporate Sustainability Reporting Directive (CSRD) which updates and broadens the requirements of the Non-Financial Reporting Directive, requires more concrete environmental disclosures by companies such as their net zero strategies (Article 19a). ${ }^{9}$ This is coupled with a requirement in the Taxonomy Regulation to disclose how and to what extent the company activities are associated with economic activities that qualify as environmentally sustainable under the same regulation (Article 8). ${ }^{10}$ It is hoped that such provisions would prevent 'greenwashing' by companies and provide more information for capital market participants who then can make better decisions on where and when to allocate capital and also intervene in companies whose transition to net zero staggers. ${ }^{11}$

Institutional investors, especially index funds, have growing influence in public companies across jurisdictions. ${ }^{12}$ Insomuch that their substantial exposure to systematic risks such as climate risk through portfolio companies made them popular candidates to bring companies in

\footnotetext{
7 See European Commission, 'Inception Impact Assessment - Ares(2020)4034032' (Jul. 30, 2020), https://ec.europa.eu/info/law/better-regulation/have-your-say/initiatives/12548-Sustainable-corporategovernance en, last accessed Sept. 21, 2021.

${ }^{8}$ See ibid (considering "shortcomings in corporate legislation and governance codes [that] ... foster directors' accountability towards shareholders and do not sufficiently cover the interest of other stakeholders" as drivers of sustainability problems). This document and the underlying study from Ernst \& Young seem to conflate shareholder value approach and short-termism. See Alex Edmans et al., 'Call for Reflection on Sustainable Corporate Governance' (Apr. 07, 2021), https://ecgi.global/news/call-reflection-sustainable-corporategovernance.

9 Proposal for a DIRECTIVE OF THE EUROPEAN PARLIAMENT AND OF THE COUNCIL amending Directive 2013/34/EU, Directive 2004/109/EC, Directive 2006/43/EC and Regulation (EU) No 537/2014, as regards corporate sustainability reporting, COM/2021/189 final, available at https://eur-lex.europa.eu/legalcontent/EN/TXT/?uri=CELEX:52021PC0189.

${ }^{10}$ Regulation (EU) 2020/852 of the European Parliament and of the Council of 18 June 2020 on the establishment of a framework to facilitate sustainable investment, and amending Regulation (EU) 2019/2088, OJ L 198, 22.6.2020, available at https://eur-lex.europa.eu/legal-content/EN/TXT/?uri=celex:32020R0852.

${ }^{11}$ See also Philipp Krueger, Zacharias Sautner, Dragon Yongjun Tang \& Rui Zhong, The Effects of Mandatory ESG Disclosure Around the World, ECGI Finance Working Paper No. 754/2021, available at https://papers.ssrn.com/sol3/papers.cfm?abstract id=3832745 (suggesting that "mandatory ESG disclosure has beneficial informational and real effects."); Ioannis Ioannou \& George Serafeim, 'The Consequences of Mandatory Corporate Sustainability Reporting', in The Oxford Handbook of Corporate Social Responsibility: Psychological and Organizational Perspectives, Abagail McWilliams et al. (eds.), 2019, pp (suggesting that "current efforts to increase transparency around organizations' impact on society are effective at improving disclosure quantity and quality as well as corporate value.").

${ }^{12}$ See, e.g., Ronald J. Gilson \& Jeffrey N. Gordon, The Agency Costs of Agency Capitalism; Activist Investors and The Revaluation of Governance Rights, (2013) (113) Columbia Law Review 863; Lucian A. Bebchuk \& Scott Hirst, Index Funds and the Future of Corporate Governance: Theory, Evidence and Policy, (2019) 119 Columbia Law Review 2029; Adriana De La Cruz, Alejandra Medina \& Yun Tang, Owners of the World's Listed Companies, OECD Capital Market Series (2019), available at https://www.oecd.org/corporate/ca/Owners-of-theWorlds-Listed-Companies.pdf.
} 
line with the global net zero ambitions. ${ }^{13}$ Relatedly, sustainability has become one of the main issues of engagement and monitoring in investee companies, especially for the Big Three asset managers. ${ }^{14}$ Given the demand from beneficiaries and increasing market expectations, many institutional investors and asset managers also commit themselves to responsible investing which incorporates ESG ('environment, social \& governance') issues into their investment process. $^{15}$

It is fair to say that in response to this growing concern with climate change, companies have been taking some steps in this regard. In their sustainability reports, many (public) companies now disclose their GHG emissions and put forward a net zero carbon strategy, the credibility and ambitiousness of which can be surely debated. ${ }^{16}$ There are many reasons for this 'sustainability' or 'ESG' response on the part of companies: financial risks, reputational threats, market pressures or intrinsic motivations etc. ${ }^{17}$

In brief, sustainability and ESG have become mainstream issues both for companies and for their institutional investors. Regulators or lawmakers around the world also scramble to have

\footnotetext{
${ }^{13}$ See, e.g., Madison Condon, Externalities and the Common Owner, (2020) 96 Washington Law Review 1; Luca Enriques \& Alessandro Romano, Rewiring Corporate Law for An Interconnected World, ECGI Law Working Paper No. 572/2021 (Mar. 2021), https://papers.ssrn.com/sol3/papers.cfm?abstract id=3814822; Jeffrey N. Gordon, Systematic Stewardship, ECGI Law Working Paper No. 566/2021 (Feb. 2021), https://papers.ssrn.com/sol3/papers.cfm?abstract id=3782814\&download=yes.

${ }^{14}$ See, e.g., Alexander Dyck, Karl V. Lins, Lukas Roth \& Hannes F. Wagner, Do Institutional Investors Drive Corporate Social Responsibility? International Evidence, (2019) 131 Journal of Financial Economics 693 (finding that "[a]cross 41 countries, institutional ownership is positively associated with E\&S [environmental and social] performance [of firms] with additional tests suggesting this relation is casual."); José Azar, Miguel Duro, Igor Kadach \& Gaizka Ormazabal, The Big Three and Corporate Emissions Around The World, (2021) 142 Journal of Financial Economics 674 (finding that "the Big Three focus their engagement effort on large firms with high $\mathrm{CO} 2$ emissions in which these investors hold a significant stake" and observing "a strong and robust negative association between Big Three ownership and subsequent carbon emissions among MSCI index constituents..."). ${ }^{15}$ For example, the Principles for Responsible Investment (PRI) initiative whose signatories commit to incorporating ESG has, as of writing, over four thousand members across the world managing over US\$100 trillion worth of assets. See https://www.unpri.org/about-the-pri/annual-report-2020/6811.article, last accessed Sept. 21, 2021.

${ }^{16}$ See, e.g., John Armour, Luca Enriques \& Thom Wetzer, 'Corporate Carbon Reduction Pledges: Beyond Greenwashing' (Jul. 2, 2021), Oxford Business Law Blog, available at https://www.law.ox.ac.uk/business-lawblog/blog/2021/07/corporate-carbon-reduction-pledges-beyond-greenwashing; Joeri Rogelj, Oliver Geden, Annette Cowie \& Andy Reisinger, Three Ways to Improve Net-Zero Emissions Targets, (2021) 591 Nature 365 ("[v]ague claims by ... companies will lull the world into missing its climate goal.").

${ }_{17}$ See, e.g., Simon Cadez, Albert Czerny \& Peter Letmathe, Stakeholder Pressures and Corporate Climate Change Mitigation Strategies, (2018) 28 Business Strategy and the Environment 1 (finding that "market pressures for reducing GHG emissions, perceived GHG-related regulatory uncertainty and environmental strategy focus are important determinants of corporate GHG reduction strategies which, in turn, enhance GHG-related performance.").
} 
companies and their investors incorporate and achieve sustainability to reduce adverse environmental impacts emanating from business operations.

Yet, a big part of this sustainability or ESG story remains missing: workforce. Although due to the urgency of climate change, environmental aspects have come to the forefront, sustainability as a concept also encompasses 'social' sustainability which embraces the idea of "identifying and managing business impacts, both positive and negative, on people" including the employees of a company. ${ }^{18}$ ESG has similarly a 'social' part in it. ${ }^{19}$ But, there are inherently tensions between environmental and social concerns, especially in terms of climate change and transition to net zero in companies.

Clearly, unmitigated climate change without adaptation measures will result in substantial harms for employees. They may be forced to migrate to other areas, lose their jobs in industries that depend on a stable and sustainable ecosystem (such as agriculture or fisheries), or may have more work-related stress, for example, due to extreme temperatures ${ }^{20}$ Climate action that reduces greenhouse gas emissions and promotes transition to an environment-friendly set-up is also projected to have overall a positive impact on employment, especially by creating new and diverse employment opportunities. ${ }^{21}$ However, unfortunately, "the intended transition to an environmentally sustainable, climate-neutral economy is not socially inclusive by default." ${ }^{22}$ Adverse employment impacts are to be expected in companies in certain sectors and some regions that will have to execute an extensive transformation to reduce their GHG emissions and to ultimately stay on a path consistent with the net zero ambitions. ${ }^{23}$

\footnotetext{
${ }^{18}$ See https://www.unglobalcompact.org/what-is-gc/our-work/social, last accessed Sept. 21, 2021. See also the definition of 'sustainable investment' in the Sustainable Finance Disclosure Regulation in the EU, which covers social as well as environmental aspects. Regulation (EU) 2019/2088 of the European Parliament and of the Council of 27 November 2019 on sustainability-related disclosures in the financial services sector, OJ L 317, 9.12.2019, art. 2(17), available at https://eur-lex.europa.eu/legal-content/EN/TXT/?uri=celex\%3A32019R2088. UN's Sustainable Development Goals also include this social dimension. The goal \#8 aims at "[p]romoting sustained, inclusive and sustainable economic growth, full and productive employment and decent work for all." See https://sdgs.un.org/goals/goal8, last accessed Sept. 30, 2021.

${ }^{19}$ See, e.g., https://www.spglobal.com/en/research-insights/articles/what-is-the-s-in-esg, last accessed Sept. 21, 2021.

${ }^{20}$ See, e.g., International Labour Organization ('ILO'), 'The Employment Impact of Climate Change Adaptation: Input Document for the G20 Climate Sustainability Working Group' (Aug. 2018), p. 13-19, available at https://www.ilo.org/wcmsp5/groups/public/---ed_emp/documents/publication/wcms_645572.pdf.

${ }^{21}$ See $i b i d$, at 21 et seq.; European Commission, 'Employment and Social Developments in Europe: Sustainable Growth for All: Choice for The Future of Social Europe' (Jun. 2019), p. 203, available at https://op.europa.eu/en/publication-detail/-/publication/747fefa1-d085-11e9-b4bf-01aa75ed71a1/language-en.

${ }^{22}$ European Commission, 'Employment and Social Developments in Europe', supra note 21, at 172.

${ }^{23}$ See ibid., at 170.
} 
Examples of this strain between social and environmental interests are increasingly visible. Recently, in an attempt to divest its assets out of step with the electric transformation and free up capital to invest in this transformation, Volkswagen management wanted to perform an extensive restructuring, including selling its Lamborghini and Ducati brands, which reportedly resulted in a clash with labour and led to these brands being kept. ${ }^{24}$ This tension has also had strong political implications. For example, the decision of when to phase out coal is currently highly political in Germany (Kohleausstieg) where different political parties argue for different timelines due to its implications for labour, ${ }^{25}$ energy and the attainment of climate targets. ${ }^{26}$ In Australia, the world's second-biggest exporter of coal by volume, the Liberal-National Coalition prevailed over the Labour party twice in recent elections, unexpectedly with the support of coal-dependent communities and workers which the former promised to protect and bolster while the latter had no credible plan for their future. ${ }^{27}$ In France, the environmental agenda of the President Emmanuel Macron, especially higher fuel taxes, triggered highly intensive and disruptive protests across the country, known as 'yellow vests (gilets jaunes) protests or movement'. The new carbon tax did not found acceptance among a substantial number of citizens, especially workers who commute or use fuel on the agricultural land. ${ }^{28}$ What is worse, populist politics may fuel the anxiety of vulnerable communities at risk from climate policies and use it to promote the anti-climate action although, as stated, evidence suggests that green policies and climate action should not have an adverse impact on employment overall. ${ }^{29}$ Section II will more closely examine and discuss the impact of the net zero transition on workforce.

\footnotetext{
${ }^{24}$ Michael Taylor, 'Points Win for Diess on Boardroom Battle Over Volkswagen's EV Future', Forbes (Dec. 14, 2020), https://www.forbes.com/sites/michaeltaylor/2020/12/14/points-win-for-diess-in-boardroom-battle-overvolkswagens-ev-future/?sh=5c141c227c57, last accessed Sept. 22, 2021; Peter Campbell \& Joe Miller, 'Electric Hypercar Group Rimac To Take Control of VW's Bugatti', Financial Times (Jul. 5, 2021), https://www.ft.com/content/56be5f08-fe6e-481f-ba6d-71ef49d2cfc4.

${ }^{25}$ It is estimated that 60,000 jobs are directly or indirectly dependent on coal. See European Commission, 'Employment and Social Developments in Europe', supra note 21, at 184.

${ }^{26}$ See generally Louisa Raitbaur, The New German Coal Laws: A Difficult Balancing Act, (2021) 11 Climate Law 176.

${ }^{27}$ See Nick Robins \& James Rydge, 'Why A Just Transition Is Crucial For Effective Climate Action’ (Sept. 2019), p. 13, available at https://www.unpri.org/inevitable-policy-response/why-a-just-transition-is-crucial-foreffective-climate-action/4785.article. See also Jamie Smyth, 'Climate Change: Australia Wrestles With Its Coal Mining Dilemma', Financial Times (May 3, 2021), https://www.ft.com/content/262db450-e619-4397-a46dcce6c8ec83a9, last accessed Oct. 5, 2021 (noting that "[a]nalysts cite the party's pledge to cut 2030 emissions by 45 per cent when compared with 2005 levels, as a key factor that lost Labor coal mining seats...").

${ }^{28}$ See, e.g., Bate Felix, 'France's Macron Learns The Hard Way: Green Taxes Carry Political Risks', Reuters (Dec. 2, 2018), https://www.reuters.com/article/us-climate-change-france-protests-idUSKBN1O10AQ, last accessed Sept. 22, 2021.

${ }^{29}$ Among the reasons why the US during the Trump administration pulled out of the Paris Agreement was the allegation that it would cost millions of jobs in the US, including the coal industry as the President Trump declared: "I happen to love the coal miners". See Robins \& Rydge, supra note 27, at 12. For further political implications,
} 
As stated, a longstanding problem has been the imposition of externalities by the companies on the environment and employees for the pursuit of profits. The mantra of shareholder wealth maximisation has been seen by some as the main culprit for the adverse impacts on the environment and people because at least in the short-term, shareholders' financial interests dictated prioritizing profits. ${ }^{30}$ Similarly, in terms of climate change, discourse sometimes gets directed at the question of how shareholder wealth maximisation can be a barrier to a swift and decisive climate action. This can hold true; yet, increasingly, shareholders' and environmental interests are becoming aligned. ${ }^{31}$ Climate change poses many financial risks for the companies and putting companies on a path in line with the net zero ambitions should also benefit shareholders financially. ${ }^{32}$ On the other hand, what remains underappreciated is the potential clash of the interests of workforce and environment, at least in the short-term.

Just transition becomes important at this point, which is defined as sharing widely the benefits of transition to a green economy and supporting those who stand to lose economically in this transition. ${ }^{33}$ Otherwise, the clash has the potential to slow down or derail the necessary and swift climate action in societies and companies as the Committee on Climate Change in the UK emphasised:

see ibid., at 13, Box 3. For a detailed description of the struggles the Biden administration faces in decarbonising the US economy, see Eric Rosenbaum, 'Biden's Climate Change Plan and The Battle For America's Most Threatened Workers', CNBC (Jan. 31, 2021), https://www.cnbc.com/2021/01/31/bidens-climate-change-planand-americas-most-threatened-workers.html, last accessed (Oct. 06, 2021).

${ }^{30}$ See, e.g., Beate Sjåfjell, Andrew Johnston, Linn Anker- Sørensen \& David Millon, 'Shareholder Primacy: The Main Barrier to Sustainable Companies', in Company Law and Sustainability: Legal Barriers and Opportunities, Beate Sjåfjell \& Benjamin J. Richardson (eds.), 2015, pp. 79-147, at 125 (stating that shareholder primacy is "the fundamental barrier to the promotion of environmentally sustainable companies ..."); Leo E. Strine, Jr., Restoration: The Role Stakeholder Governance Must Play in Recreating a Fair and Sustainable American Economy: A Reply to Professor Rock, (2021) 76 The Business Lawyer 397, 399 (noting that “... the outcomes of a corporate governance system that has increased the power of stockholders, in the form of institutional investors, and decreased the power of workers and other corporate stakeholders are unsustainable, both in terms of their effect on the environment and on the social fabric.").

${ }^{31}$ Generally, there is a changing coalition between shareholders and stakeholders. Employees' interests are aligned with shareholders' interests in the cases where the companies' success (which should benefit employees and increase the share value) stems from polluting. This may be the case in the example of Volkswagen. See Martin Gelter, 'Employee Participation in Corporate Governance and Corporate Social Responsibility', in Handbook on the Economics of Social Responsibility: Individuals, Corporations and Institutions, Lorenzo Sacconi \& Giacomo Degli Antoni (eds.), 2018, pp.

32 See, e.g., Soh Young In, Ki Young Park \& Ashby Monk, 'Is 'Being Green' Rewarded in the Market?: An Empirical Investigation of Decarbonization and Stock Returns' (Apr. 16, 2019), available at https://papers.ssrn.com/sol3/papers.cfm?abstract_id=3020304 (finding that "an investment strategy of 'long carbon-efficient firms and short carbon-inefficient firms' would earn abnormal returns of 3.5-5.4\% per year."); Philip Krueger, Zacharias Sautner \& Laura T. Starks, The Importance of Climate Risks for Institutional Investors, (2020) 33 The Review of Financial Studies 1067 (finding that "institutional investors believe climate risks have financial implications for their portfolio firms and that these risks, particularly regulatory risks, already have begun to materialize.”).

${ }^{33}$ See https://www.ebrd.com/what-we-do/just-transition, last accessed Sept. 22, 2021. 
"[i]f the impact of the move to net-zero emissions on employment and cost of living is not addressed and managed, and if those most affected are not engaged in the debate, there is a significant risk that there will be resistance to change, which could lead the transition to stall." ${ }^{34}$

In any case, a net zero transition without efforts to ameliorate potential losses for the workforce will do not justice to social equity. ${ }^{35}$ Section III will more closely scrutinize and address the implications of the potential clash between environmental and social interests and the necessity of just transition in companies.

As explained above, with the growing concern of climate change, many legal or market measures focus on achieving sustainability in companies. Yet, any action that remains uninformed of the need to reconciliate the potentially conflicting environmental and social interests will be ineffective or create undesirable consequences. Companies and institutional investors which are considered and encouraged as likely candidates to promote sustainability in investee companies will need to take account of the implications of the potential conflict between employees and climate action, and the need for just transition. Section IV will more closely examine these issues, particularly the incorporation of just transition into 'sustainable corporate governance and finance', based on the discussions of directors' duties \& executive remuneration, sustainability disclosures, institutional investors' engagement, and green finance.

In brief, I argue that how directors' duties and executive remuneration are shaped and designed might have different implications for addressing the potential conflicts in the companies' decarbonisation and achieving just transition while case studies show that the former might not matter much. Furthermore, information relevant to such conflicts and to just transition should be within the scope of sustainability disclosures. These elements are also relevant to institutional investors and call for their engagement. Lastly, green finance might play a similarly important role in not only achieving net zero transition but also in solving these conflicts and making it a just transition.

\footnotetext{
${ }^{34}$ Committee on Climate Change, 'Net Zero: The UK's contribution to stopping global warming' (May 2019), p. 255, available at https://www.theccc.org.uk/publication/net-zero-the-uks-contribution-to-stopping-globalwarming/.

${ }^{35}$ Social equity implies an equitable balance of costs and benefits of climate action across different parts of society.
} 
Overall, the purpose of this article is not to paint company workforce as the ultimate barrier to a speedy transition to net zero but to highlight underappreciated tensions that can happen between different stakeholders of a company and discuss their implications for the climate action in companies. In doing so, it aims to inform legal or market reforms and contribute to achieving sustainable corporate governance in a just and effective way.

\section{The impact of the transition to net zero on workforce}

The transition to net zero is overall expected to have a positive impact on employment. ${ }^{36}$ This is thanks to various factors such as the growth of environment-friendly sectors and investment in the 'green' infrastructure, which should create additional jobs. ${ }^{37}$ Government policies to support employment (such as recycling of carbon revenues) is also a major driver. ${ }^{38}$ For example, in the EU, compared with the baseline, the $1.5^{\circ} \mathrm{C}$ scenarios (implying net zero emissions by 2050) indicate potential gains of $0.6 \%$ to $0.9 \%$, or about 1.5 to 2 million jobs in terms of total employment in $2050 .{ }^{39}$

However, on the micro-level, there will be job-related losses for a significant number of people, at least in the short-term, which are aggravated for certain sectors and regions. ${ }^{40}$ The usual suspects include fuel extraction and mining, utilities, transport, manufacturing (especially steel,

\footnotetext{
${ }^{36}$ See, e.g., The Secretariat of United Nations Framework Convention on Climate Change, 'Just Transition of the Workforce, and The Creation of Decent Work and Quality Jobs' (Apr. 21, 2020), p. 17, available at https://unfccc.int/documents/226460 ("Most studies that have investigated the net impact on employment of environmental policy measures suggest that it is positive."); ILO, 'The Employment Impact of Climate Change Adaptation', supra note 20, at 21 ("The transition to a low-GHG economy is expected to lead to a net creation of jobs.'); OECD, 'Employment Implications of Green Growth: Linking Jobs, Growth, and Green Policies' (Jun. 2017), p. 2, available at https://www.oecd.org/environment/Employment-Implications-of-Green-Growth-OECDReport-G7-Environment-Ministers.pdf ("Ambitious green policies that improve environmental quality while maintaining economic growth do not have to harm overall employment - if they are well implemented.").

${ }^{37}$ Ibid.

${ }^{38}$ Ibid.

${ }^{39}$ European Commission, 'Employment and Social Developments in Europe', supra note 21, at 181.

${ }^{40}$ See Robins \& Rydge, supra note 27, at 3 (stating that "...there will be significant implications [of the lowcarbon transition] in key sectors and regions, raising profound issues for workers and communities."); Francesco Vona, Job Losses and Political Acceptability of Climate Policies: Why The 'Job-Killing' Argument Is So Persistent And How to Overturn It, (2019) 19 Climate Policy 524, 525 (“... evidence suggests that, although the aggregate effect of climate policies is unquestionably positive in terms of health and probably neutral in terms of employment, losses for displaced workers in polluting industries can be large."); The Secretariat of UNFCCC, 'Just Transition of the Workforce, and The Creation of Decent Work and Quality Jobs', supra note 36, at 17 ("The likelihood that the overall net employment outcome will be positive should not obscure the reality that far-reaching mitigation policies will change global, regional and national economies in potentially profound ways and severely disrupt the lives of affected workers and their communities.”).
} 
cement and chemicals) and agriculture. ${ }^{41}$ According to a UN report, there are 1.47 billion jobs in these sectors critical to climate stability. ${ }^{42}$ Especially, 'stranded assets' present an important problem because they can directly translate into 'stranded jobs' ${ }^{43}$ For example, in the fossil fuel extractive industries, a loss of up to $60 \%$ of jobs is expected. ${ }^{44}$ In certain communities, direct job losses can amplify the effect by creating indirect job losses. ${ }^{45}$

Furthermore, the creation of new jobs does not necessarily offset the job-related losses, especially due to labour market frictions. ${ }^{46}$ First, labour force may not adapt to new skill requirements in the green economy, at least not as fast as may be necessary, which will leave some workers unemployed. ${ }^{47}$ Second, companies or regions that have a lead in certain sectors and employ a substantial number of people may not have the same lead when transitioning to green economy, which may mean the employment of fewer people. ${ }^{48}$ For example, a car company that has a lead in the manufacture of conventional cars with internal combustion engines may not be able to maintain that lead in the manufacture of electric vehicles. Third, new employment opportunities may not appear at the right time and place to offset job losses. ${ }^{49}$ The loss of employment is reinforced by the 'stickiness' of workers who may be unable or unwilling to move to other regions to find employment in the transformed sector or a totally new sector. ${ }^{50}$ What also matters is the qualitative considerations, namely, jobs that are created

\footnotetext{
${ }^{41}$ These sectors together account for close to $90 \%$ of all $\mathrm{CO}_{2}$ emissions in the EU. See European Commission, 'Employment and Social Developments in Europe', supra note 21, at 175.

${ }^{42}$ The Secretariat of UNFCCC, 'Just Transition of the Workforce, and The Creation of Decent Work and Quality Jobs', supra note 36, at 35-36.

${ }^{43}$ See Robins \& Rydge, supra note 27, at 9 (writing that if the net zero transition is poorly managed, "countries and regions could see not only 'stranded assets' but also 'stranded workers' and 'stranded communities'.”).

${ }^{44}$ European Commission, 'Employment and Social Developments in Europe', supra note 21, at 181.

${ }^{45}$ See Rosenbaum, supra note 29 (citing the executive director of the Just Transition Fund who notes that "[f]or every direct job lost in a power plant or in mining, the community loses four indirect jobs...").

46 European Commission, 'Employment and Social Developments in Europe', supra note 21, at 188 (acknowledging this fact); Georg Zachmann, Gustav Fredriksson \& Grégory Claeys, The Distributional Effects of Climate Policies (Bruegel 2018), p. 64 (stating that “... given the specific nature of the skills needed, combined with the EU's low labour mobility, between sectors and between geographical areas, the transition could result in severe bottlenecks in the economy, which could lead to transitional unemployment and to unfilled vacancies.").

${ }^{47}$ European Commission, 'Employment and Social Developments in Europe', supra note 21, at 188. See also Vona, supra note 40, at 525 ("“a] successful relocation from 'brown' to 'green' jobs can ... be particularly difficult given the potentially large differences in their skill requirements."). This relates to the idea of firm-specific human capital where employees make firm-specific investments and have non-transferable skills. See, e.g., Margaret Blair, 'Firm-Specific Human Capital and Theories of the Firm', in Employees and Corporate Governance, Margaret Blair \& Mark Roe (eds.), 2000, pp. 58-90.

${ }^{48}$ European Commission, 'Employment and Social Developments in Europe', supra note 21, at 188.

${ }^{49}$ The Secretariat of UNFCCC, 'Just Transition of the Workforce, and The Creation of Decent Work and Quality Jobs', supra note 35, at 18 (stating that "[t]he low-carbon economy may not create (sufficient numbers of) jobs in the locations where jobs are lost in the conventional economy. Likewise, green jobs creation may not happen at the same time, or at the same pace, as conventional job losses occur.").

${ }^{50}$ See also Robins \& Rydge, supra note 27, at 3 (stating that “...there could be significant adjustment issues as workers need to move from declining to expanding sectors, firms and job types"); Rosenbaum, supra note 29
} 
must be decent jobs on par with the jobs lost, especially in terms of financial considerations, if the former is to counterbalance the latter. ${ }^{51}$

Therefore, the transition to net zero by 2050 will necessarily affect workforce and create strains between it and the environmental interests. The likely causes of tensions in companies between environmental and social concerns can be generalised in the following way: (i) divestment or decommissioning of 'brown' assets (to reduce carbon footprint and free up capital to invest in efficiency) vs. the potential to lay off workers and (ii) transformation of business (for example from internal combustion to electric engines) vs. the potential to lose relevant skills, have lower wage or get laid off. The same tension can arise in the companies' value chain. Companies may have to choose between environmental-friendly supply chain (which is good for environmental sustainability and addressing Scope 3 emissions) $)^{52}$ vs. worker-friendly supply chain (which is good for social sustainability) if they do not co-exist in the potential suppliers.

The clash of the social and environmental concerns is not new. Whenever the protection of environmental interests has adverse consequences for the workforce in an enterprise or community, it may bring them at loggerheads. Examples in this regard abound. For instance, while the environmental groups were campaigning for the closure of Diablo Canyon, a commercial nuclear power plant in the State of California operated by Pacific Gas and Electric (PG\&E), unions representing workers fought hard to keep the plant open as long as possible, which led to a compromise deal in the end to address concerns from both sides. ${ }^{53}$ Another example involves one of the Europe's biggest steelworks, ILVA, Taranto in Italy which had an appalling environmental record, causing countless deaths and illnesses in the community. Yet, supported by unions that were against the closure of steel plants, the government allowed it to

(citing the director of the Yale Program on Climate Change Communication who notes that retrenched workers do not want to leave places where they have lived for generations). See also Abhijit B. Banerjee \& Esther Duflo, Good Economics for Hard Times (Public Affairs 2019), pp. (noting that “... labor markets tend to be sticky. People do not move even when labor market conditions would suggest they ought to ...").

${ }^{51}$ See Vona, supra note 40, at 529 ("[i]t is not only skill gaps that are important, but also average quality of the non-brown jobs available in the local economy."); The Secretariat of UNFCCC, 'Just Transition of the Workforce, and The Creation of Decent Work and Quality Jobs', supra note 35, at 18 ("Another dimension which is important - along with the increased number of jobs created, lost or transformed - is the quality of employment. Jobs created in the transition to a low-carbon economy must be 'decent'").

${ }^{52}$ Scope 3 emissions are "all indirect emissions (not included in scope 2) that occur in the value chain of the reporting company, including both upstream and downstream emissions." See https://ghgprotocol.org/sites/default/files/standards supporting/FAQ.pdf, last accessed Sept. 29, 2021.

${ }^{53}$ For a more detailed exposition, see Samantha Smith, 'Just Transition: A Report for the OECD' (May 2017), pp. 10-11, available at https://www.oecd.org/environment/cc/g20-climate/collapsecontents/Just-TransitionCentre-report-just-transition.pdf. 
continue production without any credible environmental engagement to preserve jobs in the region, which was found legitimate by the Italian constitutional court. ${ }^{54}$

\section{The implications of the potential clash between environmental and workforce interests for the climate action in companies}

The potential conflict between environmental interests and workforce that may arise at least in the short-term have some repercussions for the decarbonisation of the economy. As depicted above, it has already affected countries in terms of governmental policies and net zero strategies. ${ }^{55}$ Similarly, it may have implications for the transition to net zero in companies.

Most importantly, these conflicts may slow down or derail the necessary swift and decisive climate action. ${ }^{56}$ Negative consequences of the transition to net zero in companies for their employees may make them unwilling and resistant to climate action to a certain degree. ${ }^{57}$ This is not to say that employees are in denial of climate change or do not accept scientific facts. They may not be also necessarily against the climate action. However, when the latter is directly against the self-interest, then the acknowledgement of climate change and the support for the necessary climate action will not translate into a frictionless transition in the companies. ${ }^{58}$ This may make the transition slower than socially optimal and derail it in the extreme cases. There may be also a negative feedback loop: as companies delay the adequate

\footnotetext{
${ }^{54}$ See Vona, supra note 40, at 527. See also Tom Kington, 'Italian Town Fighting For Its Life Over Polluting Ilva Steelworks' (Aug. 17, 2012), The Guardian, https://www.theguardian.com/world/2012/aug/17/italy-ilvasteelworks-cancer-pollution.

55 See the text accompanying supra notes 25-29.

${ }^{56}$ See Robins \& Rydge, supra note 27 , at 9 (stating that failing to address negative consequences could slow or even stall climate progress).

${ }^{57}$ This can be amplified by the negative consequences of globalisation and automation, especially for low-skilled workers, which can lead to distortions in the perceptions in terms of what is the real cause of job loss. See Vona, supra note 40, at 527.

58 See also European Commission, 'Employment and Social Developments in Europe', supra note 21, at 185 (noting that discontent and backlash may "reduce public support for climate action and related policies, thereby compromising the effective transition to a green, more circular and climate-neutral economy") and at 191 (stating that "[d] espite widespread awareness of climate change and of the responsibility and urgency to act, support for climate action is mixed, and stronger for standards than taxation."); Rosenbaum, supra note 29 (citing the head of the Office of Just Transition in the state of Colorado, who states that coal communities "are [now] being told for the good of humanity they need to stop. That is a hard message to take, even if you understand and believe in it, and if you don't, it becomes even harder."). See also Martin Gelter, Sustainability and Corporate Stakeholders (Jul. 7, 2021), Oxford Business Law Blog, https://www.law.ox.ac.uk/business-lawblog/blog/2021/07/sustainability-and-corporate-stakeholders (suggesting that for a more environmentalist policy, employees may not be willing to sacrifice their jobs which are "more salient for one's identity than investment positions, and more visible within the respective social group.").
} 
action, the more change will need to happen on a compressed timescale, which means more severe impacts on the workforce. ${ }^{59}$

For example, a survey among a large sample of private sector employees in Germany found that although they are largely in favour of climate protection measures in companies, their support drops significantly when they become directly impacted. ${ }^{60}$ A study conducting a general review of case-studies and empirical evidence finds that "the job losses ascribed (correctly or incorrectly) to climate policies have substantial impacts on the willingness of affected workers to support these policies." 61

The potential negative consequences for the employees, particularly the job loss that may not be easy to replace, may especially exacerbate the existent and acute collective action problems for the protection of the environment. ${ }^{62}$ Although the necessity of climate action is accepted, employees may push for the deferment of substantial transition in their companies because they see no or very little similar action in other companies in the same or different jurisdiction. If the same happens in every company, then climate action will unravel.

One may argue that unless employees are sufficiently represented on the board level (like codetermination), ${ }^{63}$ their influence will be non-existent. This does not necessarily hold true. Especially, the voice and concerns the unions express and the action they mobilise can be a true force in directing and affecting transition to net zero in companies. ${ }^{64}$ The following quote

${ }^{59}$ The Secretariat of UNFCCC, 'Just Transition of the Workforce, and The Creation of Decent Work and Quality Jobs', supra note 35, at 18 .

60 See for the survey, https://www.bertelsmann-stiftung.de/de/themen/aktuellemeldungen/2021/september/beschaeftigte-fordern-mehr-klimaschutz-der-unternehmen, last accessed Sept. 30, 2021 (in German). For a summary in English, see https://www.cleanenergywire.org/news/german-employeesmostly-back-more-climate-action-companies-are-reluctant-take-part-survey, last accessed Sept. 30, 2021.

61 Vona, supra note 40, at 524.

62 Environment is a common good, and the protection of common goods suffers under the collective action problem. This is also known as the "tragedy of the commons". Garrett Hardin, The Tragedy of the Commons, (1968) 162 Science 1243.

${ }^{63}$ On co-determination, see, e.g., Klaus Hopt \& Patrick C. Leyens, The Structure of the Board of Directors: Boards and Governance Strategies in the US, the UK and Germany, ECGI Law Working Paper No. 567/2021, pp. 40-44, available at https://papers.ssrn.com/sol3/papers.cfm?abstract id=3804717; Jens Dammann \& Horst Eidenmüller, Codetermination: A Poor Fit For U.S. Corporations, 2020 Columbia Business Law Review 870.

${ }^{64}$ See also Brian R. Cheffins, Corporate Governance and Countervailing Power, (2019) 74 The Business Lawyer 1 (counting "organized labor" as one of the external mechanisms that can operate as significant constraints on managerial discretion). 
from the president of one of the biggest unions in Australia (CFMEU Mining and Energy Union) reflects this purpose:

"[c]limate policies can achieve energy transition with or without justice. That may suit people who are solely focused on the emissions outcome. It may also suit some business leaders who like to remind us of the terrible consequences of stranded assets and investment uncertainty. It certainly doesn't suit the thousands of workers and their communities who face certain unemployment, the destruction of communities and generations of social crisis. The real problem will be stranded workers and stranded communities." 65

Furthermore, unions increasingly request to have a voice on major corporate decisions in the transition (such as a consent requirement). ${ }^{66}$ Some companies signed international framework agreements with union federations, containing provisions to deal with the consequences of climate change adaptation. ${ }^{67}$ In general, unions navigate between strategies of opposition, hedging or support when it comes to climate change mitigation policies, where only in the last case, they show genuine support for climate action. ${ }^{68}$

Unless frictions between environmental interests and workforce are actively addressed, there will be several arguably undesirable developments that can be expected in the decarbonisation of companies. First, companies will defer the actual and significant reduction of the GHG emissions in their operations, which will save jobs, and rely on the emergence of large-scale, reasonably-priced carbon capture technologies. ${ }^{69}$ However, unless the latter is available in the

\footnotetext{
${ }^{65}$ See Smith, supra note 53, at 9. See also ibid., at 10 (quoting a business manager of IBEW (a big labour union in North America): "I do not believe there can ever be a sustainable energy economy that is based on a disposable workforce...").

${ }^{66}$ See, e.g., https://igbce.de/igbce/themen/transformation/transformation-gestalten-177858, last accessed Sept. 29, 2021 (IG BCE, one of the largest trade unions in Germany, proposing a new decision process in the case of far-reaching corporate decisions such as company sales, plant closures or mass layoffs).

${ }^{67}$ The agreement signed by ENGIE (previously known as GDF Suez), a French multinational utility company, stipulates that "any necessary adaptation takes place in a way that protects the rights and interests of workers and that the impact of any such changes are designed and implemented in an agreed, fair manner." See https://www.world-psi.org/sites/default/files/documents/research/gdf-gfa-english.pdf, last accessed Sept. 29, 2021.

${ }^{68}$ Adrien Thomas \& Nadja Doerflinger, Trade Union Strategies on Climate Change Mitigation: Between Opposition, Hedging and Support, (2020) 26(4) European Journal of Industrial Relations 383. Opposition involves denying the scientific consensus on climate change and outright opposing climate change mitigation policies, which remains rare. Ibid., at 388-89. Hedging involves accepting the scientific consensus on climate change and supporting in principle the need of decarbonisation but also seeking to minimise potential attempts that could expose them to negative employment implications. Ibid., at 390. Support entails outright support for decarbonisation policies and proactively engaging with potential negative impacts. Ibid., at 391 .

${ }^{69}$ See also Smyth, supra note 27 (stating that the Australian government wants to rely on new technology to meet its modest emission reduction targets).
} 
short-term, it will be very difficult for companies to get on a path in line with net zero by 2050 if they defer climate action. ${ }^{70}$ Second, to be able to hit their climate targets, companies will increasingly depend on carbon offsets (other than carbon capture), rather than making their operations more sustainable. Carbon offsets are means to offset any remaining carbon emissions from the company operations by removing carbon from the planet (for example by forestation). ${ }^{71}$ However, carbon offsets are necessarily limited and should be only a last resort to address carbon emissions. ${ }^{72}$ If most companies prefer carbon offsets to a large degree to maintain 'business as usual' and thus save jobs, there will not be enough opportunities for all of them. Third, in order to invest in research and development to develop green services and products in the transition to net zero, most companies need capital. ${ }^{73}$ Some companies may prefer to free up some capital by shutting down carbon-intensive business and invest proceeds in green operations. Yet, this may not be possible if the shutdown means substantial job losses that cannot be compensated in the short-term by re-deploying employees. ${ }^{74}$ Lastly, the protection of workforce interests may serve as an excuse for directors/managers who prefer a 'quite life' and are not ready to execute a substantial transition to net zero in the companies they manage. ${ }^{75}$

Good news is that a relatively frictionless transition in companies that serves the interests of the environment but also employees can be possible. This transition is called 'just transition' ${ }^{76}$ It generally means supporting those who stand to lose economically in the

\footnotetext{
${ }^{70}$ See Eric Rosenbaum, 'Climate Experts Are Worried About the Toughest Carbon Emissions For Companies To Capture', CNBC (Aug. 28, 2021), https://www.cnbc.com/2021/08/18/apple-amazon-exxon-and-the-toughestcarbon-emissions-to-capture.html, last accessed Sept. 30, 2021.

${ }^{71}$ On carbon offsets, see https://www.offsetguide.org/understanding-carbon-offsets/what-is-a-carbon-offset/, last accessed Sept. 30, 2021.

${ }^{72}$ See Catherine Clifford, 'Bank of America: Carbon Offset Market May Need to Grow Fiftyfold to Meet 2050 Net-zero Emissions Goals', CNBC (Sept. 27, 2021), https://www.cnbc.com/2021/09/27/bank-of-america-carbonoffset-market-to-X-50-to-meet-net-zero-goals.html, last accessed Sept. 30, 2021. See also Raphael Calel, Jonathan Colmer, Antoince Dechezleprêtre \& Matthieu Glachant, 'Do Carbon Offsets Offset Carbon?', CESifo Working Paper No. 9368 (2021), available at https://www.cesifo.org/DocDL/cesifo1_wp9368.pdf.

${ }^{73}$ According to a recent IPCC report, “...limiting global warming to $1.5^{\circ} \mathrm{C}$ are projected to involve the annual average investment needs in the energy system of around 2.4 trillion USD2010 between 2016 and 2035, representing about $2.5 \%$ of the world GDP." See IPCC, 'Special Report', supra note 5, at 22.

${ }^{74}$ See the text accompanying supra note 24 (recounting the Volkswagen story).

${ }^{75}$ See, e.g., Ryan Flugum \& Matthew E. Souther, 'Stakeholder Value: A Convenient Excuse for Underperforming Managers?' (Aug. 2021), https://papers.ssrn.com/sol3/papers.cfm?abstract_id=3725828 (suggesting that "the push for stakeholder-focused objectives provides managers with a convenient excuse that reduces accountability for poor firm performance."). See also infra note 96.

${ }^{76}$ Just transition in a narrow sense focuses on the implications of the transition mainly for workers, also in the Paris Agreement. In a wider sense, it may cover implications for consumers, communities and citizens etc. See Robins \& Rydge, supra note 27, at 3.
} 
decarbonisation of economy and making companies sustainable. ${ }^{77}$ It was also included in the preamble of the Paris Agreement. ${ }^{78}$ Furthermore, at the COP 24 climate change conference in 2018, 53 countries signed a just transition declaration, stressing that it is "crucial to ensure an effective and inclusive transition to low greenhouse gas emission and climate resilient development, and to enhance the public support for achieving the long term goals of the Paris Agreement."79

Just transition is promising in terms of accelerating climate action because it addresses the distributional consequences of net zero transition. ${ }^{80}$ Different actors on various levels (companies, communities, regional or national governments) can contribute to just transition. For companies, it translates into entering into a social dialogue with the workers and their representatives and "creating decent jobs, reskilling and retaining workers, ensuring a social floor for workers who are retrenched and investing communities" while they design and implement their net zero strategy. ${ }^{81}$ Just transition is particularly important for carbon majors, in other words, companies operating in industries which are expected (and urged) to undergo an extensive transformation (such as fossil fuel, utilities etc.). ${ }^{82}$ Decarbonisation of these companies will have the most positive environmental impact as they are the major GHG emitters, ${ }^{83}$ but, at the same time, the social impact will also be huge. In other words, positive environmental impact of the transition in terms of climate change will be negatively correlated with its social impact, necessitating just transition to ease the impact and thus possible tension.

\footnotetext{
77 See supra note 33.

78 “...Taking into account the imperatives of a just transition of the workforce and the creation of decent work and quality of jobs in accordance with nationally defined development priorities,...". See supra note 4. Furthermore, ILO adopted guidelines to help countries manage just transition. See ILO, 'Guidelines for A Just Transition towards Environmentally Sustainable Economies and Societies for All' (2015), available at https://www.ilo.org/wcmsp5/groups/public/---ed_emp/---emp_ent/documents/publication/wcms 432859.pdf.

79 The full name of the declaration is 'Solidarity and Just Transition Silesia Declaration', available at https://cop24.gov.pl/presidency/initiatives/just-transition-declaration/. See also https://www.ilo.org/global/aboutthe-ilo/newsroom/news/WCMS_721144/lang--en/index.htm, last accessed Sept. 29, 2021 (noting just transition commitments made by close to 50 countries at an UN Climate Action Summit).

${ }^{80}$ Robins \& Rydge, supra note 27, at 10.

${ }^{81}$ Smith, supra note 53, at 6. See also GRI draft standards for coal, infra note 110, at 14 (stating that "[e]xamples of potential actions from coal organizations to ensure a just transition include providing plenty of notice of closures, collaborating with governments and unions, retraining and redeploying workers, and providing alternate investments in affected communities.").

${ }^{82}$ See supra notes 41-42 and accompanying text.

${ }^{83}$ See supra note 6.
} 
In a growing number of companies whose business operations depend(ed) on large GHG emissions, the need for a just transition is visible. ${ }^{84}$ A relatively successful example of the "just transition' is Enel. ${ }^{85}$ It is a multinational listed company with a significant share ownership by the Italian state and operates in the utilities sector. Being one of the world's major producers of clean energy, Enel has committed itself to a net zero strategy that is in line with the $1.5^{\circ} \mathrm{C}$ global warming goal. ${ }^{86}$ To achieve its decarbonisation goals, Enel launched a plan to close or repurpose its power stations representing $13 \mathrm{GW}$ of capacity and a coal mine, which will affect more than 68.000 workers. ${ }^{87}$ To address challenges for its employees, Enel has entered into a social dialogue and a framework just transition agreement with trade unions which covers retention, redeployment, reskilling and early retirement for elderly workers. ${ }^{88}$ It is operationalised through several initiatives, including (i) early retirement incentives for elderly workers; (ii) a recruitment plan for young workers, using vocational apprenticeships designed to build skills relevant for the green energy sector; (iii) "[t]raining and reskilling to ensure workers are qualified and employable ... throughout their careers"; (iv) "[r]elocation of workers through agreements negotiated between the company, the workers and their representatives." 89 As of 2019, Enel claimed that all affected workers had found new jobs or retired..$^{90}$

Just as it addresses and removes the frictions that can arise between the environmental concerns and workforce, just transition is also argued to contribute to an 'equitable' transition which ameliorates the possible negative distributional consequences of climate action in the short-

\footnotetext{
${ }^{84}$ See Smyth, supra note 27 (noting that "[i]n a growing number of companies and communities across Australia, the discussion is changing from how to save coal to the need for a just economic transition to compensate for the loss of well-paying and related jobs."); Nick Robins, Sabrina Muller \& Katarzyna Szwarc, 'From the Grand to the Granular: Translating Just Transition Ambitions into Investor Action' (Jul. 2021), available at https://www.lse.ac.uk/granthaminstitute/publication/from-the-grand-to-the-granular-translating-just-transitionambitions-into-investor-action/ (providing case studies of five European power utility companies (ENEL, EDF, E.ON, SSE, ZE PAK) in terms of their just transition action).

${ }^{85}$ See generally Serena Rugiero, 'Decarbonisation in the Italian Energy Sector: The Role of Social Dialogue in Achieving A Just Transition - The Case of Enel', in Towards A Just Transition: Coals, Cars and The World of Work, Béla Galgóczi (ed.), 2019, pp. 109-134; Robins, Muller \& Szwarc, supra note 84, at 20-23. See also Anmar Frangoul, 'The Risk of The Energy Transition Is That It Only Benefits A Few', CNBC (Jun. 23, 2021), https://www.cnbc.com/2021/06/23/risk-of-the-energy-transition-is-that-it-only-benefits-a-few-ceo-says.html last accessed Oct. 5, 2021 (featuring an interview with the CEO of Enel where he emphasised the risks of an unjust transition and the importance of reskilling for the employment in green sectors).

${ }^{86}$ See https://sciencebasedtargets.org/companies-taking-action\#table, last accessed Sept. 22, 2021.

${ }^{87}$ See https://www.wri.org/just-transitions/italy, last accessed Sept. 22, 2021.

${ }^{88}$ See ibid.; Smith, supra note 53, at 6.

${ }^{89} \mathrm{Ibid}$.

${ }^{90}$ Ibid.
} 
term. ${ }^{91}$ Furthermore, it brings home the point of an integrated approach to ESG factors to prevent what can be called as "sustainability arbitrage" (both for companies and for investors), indicating good performance on environmental matters masking poor labour practices. ${ }^{92}$

\section{The implications for 'sustainable' corporate governance and finance}

There are some potential frictions between environmental and social concerns in the context of climate action, and just transition is important to address them. Not only will it provide a more equitable transition to net zero by mitigating distributional consequences but also it will pave the way for a swift and decisive climate action in societies and companies. These findings have a couple of implications for 'sustainable' corporate governance and finance.

\section{(a) Directors' duties and executive remuneration}

Proponents of stakeholder theory ${ }^{93}$ claim that environmental externalities can be better addressed if directors do not serve only shareholders' interests. ${ }^{94}$ One may further argue that in the case of directors' duties where they serve the stakeholders' interests, companies may better manage the social implications of their transition to the low-carbon operations as directors need to take account of and balance different interests (including employees). However, it is also possible that balancing of different interests is too difficult and the process of net transition comes often to the deadlock. ${ }^{95}$ As hinted above, managerial discretion in this

\footnotetext{
${ }^{91}$ See Robins \& Rydge, supra note 27, at 9 (noting the 'equity' aspect of transition so that those less well-off as a result do not bear a disproportionate share of costs).

92 Nick Robins, Vanda Brunstig \& David Wood, 'Climate Change and The Just Transition: A Guide for Investor Action’ (Dec. 2018), p. 18, available at https://www.unpri.org/download?ac=9452.

${ }^{93}$ For a detailed survey of stakeholder theories, see Cynthia A. Williams, 'Corporate Social Responsibility and Corporate Governance', in The Oxford Handbook of Corporate Law and Governance, Jeffrey N. Gordon \& WolfGeorg Ringe (eds.), 2018, 634-78.

${ }^{94}$ See, e.g., Beate Sjåfjell, Sustainable Value Creation Within Planetary Boundaries - Reforming Corporate Purpose and Duties of the Corporate Board, (2020) 12 Sustainability 6245; Colin Mayer, Prosperity: Better Business Makes Greater Good (OUP 2018); Lynn Stout, The Shareholder Value Myth: How Putting Shareholders First Harms Investors, Corporations, and The Public (Berrett-Koehler Publishers, Inc. 2012); Simon Deakin, 'Shareholder Value and the Legal Reform of Corporate Governance', in Corporate Governance in Contention, Ciaran Driver \& Grahame Thompson (eds.), 2018, pp. 25-41.

${ }^{95}$ See also Gelter, supra note 58 (suggesting that broad-based stakeholder orientation can make decision-making processes more complex); Lucian A. Bebchuk \& Roberto Tallarita, The Illusory Promise of Stakeholder Governance, (2020) 106 Cornell Law Review 91, at 115 (noting that “... the task that stakeholderism assigns to corporate leaders is Herculean.") and at 119 (the exercise of weighing and balancing different stakeholders' interests "raises very difficult questions regarding conflicts between groups of stakeholders ..."); Mark Roe, Holger Spamann, Jesse Fried \& Charles Wang, The Sustainable Corporate Governance Initiative in Europe, (2021) 38 Yale Journal on Regulation Bulletin 133, 146 (stating that the employees' interest in stable employment
} 
regard can also be used to cloak potential managerial slack in putting their companies on a sustainable path. ${ }^{96}$ Furthermore, as long as managerial incentives remain aligned with shareholders' interest, stakeholder-orientation of directors' duties will not achieve the intended results. ${ }^{97}$

In a regime where shareholders' interests are primary in terms of directors' duties, there are different scenarios as well. First, as directors put into practice a net zero transition in their companies in line with the long-term value creation (and thus shareholders' interests), they may also identify and address the social implications of the transition and implement a just transition if it helps the company to keep up with its decarbonisation strategy. ${ }^{98}$ It is also possible that companies transition in a disorderly fashion without a due consideration of social impacts (if it is in line with shareholders' interests) when directors think that they can afford to ignore such impacts.

Ultimately, the fact that utility companies which have taken on the just transition come from different jurisdictions where different models of directors' duties apply shows that how directors' duties are shaped may not matter much in the end in this respect: Enel (Italy), EDF (France), SSE (the UK), E.ON (Germany), and ZE PAK (Poland).${ }^{99}$ It is noteworthy however that in the first two companies, the respective states have considerable share-ownership. States

is in tension with the interests of the environment and expressing scepticism that deputizing corporate boards to balance these interests and make complicated trade-offs is a good idea).

${ }^{96}$ See Bebchuk \& Tallarita, supra note 95, at 164-68 (explaining how stakeholderism can be used by managers to increase insulation and reduce accountability).

${ }^{97}$ Ibid., at 92 (indicating that "because corporate leaders have strong incentives not to protect stakeholders beyond what would serve shareholder value, acceptance of stakeholderism should not be expected to produce material benefits for stakeholders."); Lucian A. Bebchuk, Kobi Kastiel \& Roberto Tallarita, For Whom Corporate Leaders Bargain, forthcoming in Southern California Law Review (2021), available at https://papers.ssrn.com/sol3/papers.cfm?abstract id=3677155 (arguing that the reason why corporate leaders did not use their discretion to negotiate for any stakeholder protections in private equity acquisitions is their incentives not to protect stakeholders beyond what would serve shareholder value).

${ }^{98}$ As argued below, if just transition is a way of addressing a transition risk where negative consequences for employees and communities may form stumbling blocks for the transition to net zero which is necessary for the long-term value of the company, then it may become part of directors' fiduciary duties. See the text accompanying infra notes 106-107. Just transition may also be in companies' and thus shareholders' interest from another perspective: companies that do not engage with workers and communities and thus poorly manage the social impacts of their transition may face worse reputations in a way that impact their 'social licence to operate'. See Robins, Brunstig \& Wood, supra note 92, at 12. See also SSE, 'Supporting A Just Transition' (Nov. 2020), p. 3, available at https://www.sse.com/media/km5ff0fx/sse-just-transition-strategy-final.pdf (the CEO of SSE, a FTSE 100 energy company in the UK, saying that " $[\mathrm{t}]$ he prize of a fair and just transition to net zero is that the actions and investments required to decarbonise energy systems attract long-term public support and legitimacy.").

${ }^{99}$ For how these companies endevaour to achieve just transition, see Robins, Muller \& Szwarc, supra note 84, at 20-33. For an account of how boards function in these jurisdictions, see Paul Davies, Klaus J. Hopt, Richard Nowak \& Gerard Van Solinge (eds.), Corporate Boards in Law and Practice: A Comparative Analysis in Europe (OUP 2013). 
have generally an interest in ameliorating the potential negative consequences of net zero transition for employees and this may lead them to address these issues directly in the utilities companies they control as a shareholder. In the other cases, the share-ownership is either dispersed (SSE) or controlled (E.ON controlled by another company and ZE PAK controlled by individual). ${ }^{100}$

Tying executive remuneration to key metrics of sustainability performance (such as environmental score or GHG emissions etc.) of the company is on the rise. ${ }^{101}$ As it aligns the financial interests of directors/managers with the environmental performance of the company, they are incentivised to improve the latter. ${ }^{102}$ However, it appears to be a double-edged sword in the context of reconciling environmental and social interests in the net zero transition in companies. As directors/managers are (financially) incentivised to undertake a transition to lower-carbon operations, they may also address certain negative social impacts along the way to accelerate this transition, thus achieving a just and swift transition. Or, if they can afford to do so, they may become fixated only on the environmental side of the net zero transition without a due consideration of social impacts. This can be addressed by designing the components of executive remuneration in a broader way that combines environmental and social aspects of net zero transition of the company. ${ }^{103}$

\footnotetext{
${ }^{100}$ For the current share-ownership of these companies, see https://www.marketscreener.com, last accessed Oct. 19, 2021.

${ }^{101}$ See, e.g., Robert A. Ritz, Climate Targets, Executive Compensation, and Corporate Strategy, Cambridge Working Paper in Economics 2098, available at https://www.repository.cam.ac.uk/handle/1810/315202 (stating that "[a] novel aspect of the emerging corporate response is that executive compensation is being linked to climate targets."); Karen Maas \& Sanne Rosendaal, Sustainability Targets in Executive Remuneration: Targets, Time Frame, Country and Sector Specification, 25 Business Strategy and the Environment 390 (2016) (examining the current status of the use of sustainability targets in executive remuneration specified by country, sector and targets).

${ }_{102}$ See, e.g., Douglas A. Adu, Antoinette Flynn \& Colette Grey, Executive Compensation and Sustainable Business Practices: The Moderating Role of Sustainability-Based Compensation, forthcoming in Business Strategy and the Environment, available at https://onlinelibrary.wiley.com/doi/10.1002/bse.2913?af=R; Patrick Velte, Sustainable Management Compensation and ESG Performance - The German Case, 14 Problems and Perspectives in Management 17 (2016). Cf. Bebchuk \& Tallarita, supra note 95, at 160 (noting that in identifying and incorporating sustainability metrics into pay arrangements, "executives and their advisors would have the opportunity to influence pay settings in ways that would favor executives' private interests.").

${ }^{103}$ See also Bebchuk \& Tallarita, supra note 95 , at 160 (“... tying compensation to the interests of one group of stakeholders but not to the interests of a second relevant group of stakeholders might strengthen, not weaken, the incentive of corporate leaders not to give independent weight to the interests of the second group.").
} 
Companies are increasingly subject to disclosing climate-related information. This ranges from divulging raw data such as greenhouse gas emissions or environmental impact more generally ${ }^{104}$ to net zero targets and strategies and climate-related financial risks. ${ }^{105}$ Whether and to what extent companies should disclose information related to proactively identifying and addressing social impacts of their net zero transition (just transition(-related) information) under current mandatory or voluntary disclosure provisions is not clear.

Arguably, the possible frictions between climate action and employees' interest is a part of transition risk, thus a climate-related financial risk, and just transition is a way of addressing this transition risk. ${ }^{106}$ Because unless companies manage well their transition in terms of social impacts, their progress could be slowed down or stalled, amplifying the transition risk. However, the current framework promoted by the Task Force on Climate-Related Financial Disclosures (TCFD) does not cover this. ${ }^{107}$

Other widespread voluntary sustainability-related transparency initiatives also do not seem to involve just transition at the moment. Sustainability Accounting Standards Board (SASB)'s standards for "coal operations", “oil \& gas - exploration \& production", "electric utilities \& power generators", and "gas utilities \& distributors" do not refer to just transition and related

\footnotetext{
${ }^{104}$ In the EU, the Non-Financial Reporting Directive requires large and listed companies to publish information related to environmental matters. See Directive 2014/95/EU of the European Parliament and of the Council of 22 October 2014 amending Directive 2013/34/EU as regards disclosure of non-financial and diversity information by certain large undertakings and groups, OJ L 330, 15.11.2014, available at https://eur-lex.europa.eu/legalcontent/EN/TXT/?uri=CELEX\%3A32014L0095. As stated above, this directive will be revised by CSRD. In the UK, there is a quantitative emissions reporting requirement for quoted companies. See Part 7 of The Companies Act 2006 (Strategic Report and Directors' Report) Regulations 2013, available at https://www.legislation.gov.uk/ukdsi/2013/9780111540169/regulation/7.

${ }^{105}$ The Task Force on Climate-Related Financial Disclosures (TCFD) provides a widely adopted framework for the disclosure of climate-related risks. In the UK, according to a newly adopted rule by the Financial Conduct Authority, companies with premium listing are required to disclose, on a comply or explain basis, whether their climate-related disclosures are in line with the TCFD disclosures. See Listing Rule 9.8.6(8), available at https://www.handbook.fca.org.uk/handbook/LR.pdf.

${ }^{106}$ Transition risk refers to risks associated with transition to a low carbon economy which entails extensive policy, legal, technology, and market changes.

${ }^{107}$ See TCFD, 'Recommendations of the Task Force on Climate-related Financial Disclosures' (Jun. 2017), pp. 5-6, available at https://assets.bbhub.io/company/sites/60/2020/10/FINAL-2017-TCFD-Report-11052018.pdf. See also Smith, supra note 53, at 18 (arguing that recommendations of the Task Force on Climate-Related Disclosures should be expanded to include disclosure of just transition plans for vulnerable workers and communities). For a 'just transition' disclosure framework that builds on that of TCFD (strategy, governance and risk management), see Robins, Brunstig \& Wood, supra note 92, at 20.
} 
disclosures. ${ }^{108}$ Global Reporting Initiative's (GRI) general standards also do not refer to just transition-related information. ${ }^{109}$ However, with its new sector standards project, there are developments in this regard. For example, the draft sector standards for 'coal' refer to "an organization's strategy in relation to the transition to a low-carbon economy and the impacts of that transition on workers and local communities" in its "climate adaptation and resilience" section, and demand the disclosure of "any commitments, policies, and actions taken to mitigate the impacts of the transition to a low-carbon economy on workers and communities."110 Furthermore, in the "closure and rehabilitation" section, requested disclosures involve describing "how workers are consulted in advance of significant operational changes" and "the labor transition plans in place to help workers manage the transition to post-closure phase of operations (which can include redeployment, assistance with re-employment, resettlement, and redundancy payments)." 111

There is a case to make that companies should disclose their just transition plans for vulnerable workers and communities as a part of their net zero strategy. As abovementioned, the proposed CSRD in the EU updates sustainability reporting requirements for large undertakings, demanding, among others, the disclosure of net zero targets \& strategies, and implementation thereof. ${ }^{112}$ The proposal also entails the disclosure of "how the undertaking's business model and strategy take account of the interests of the undertaking's stakeholders and of the impacts of the undertaking on sustainability matters" (art. 19a/2(a)(iv)). ${ }^{113}$ This language is not clear and sufficient enough to make companies actively engage with just transition. Going forward, in line with the CSRD's aim of serving European Green Deal which refers to just transition, ${ }^{114}$ amendments can be made in the legislative process to reflect just transition in the companies' net zero plans. ${ }^{115}$

\footnotetext{
108 These are available at https://www.sasb.org/standards/download/, last accessed Sept. 23, 2021.

109 See https://www.globalreporting.org/how-to-use-the-gri-standards/gri-standards-english-language/, last accessed Sept. 23, 2021.

110 GRI, 'GRI Sector Standards Project for Coal - Exposure Draft' (Aug. 2, 2021), pp. 13-14, available at https://www.globalreporting.org/standards/standards-development/sector-standard-project-for-coal/.

${ }^{111}$ Ibid., at 20.

112 See supra note 9.

113 Ibid.

${ }^{114}$ The Preamble refers to the European Green Deal which "aims at ... ensuring that all regions and citizens of the Union participate in a socially just transition to a sustainable economic system." The European Commission committed to providing a new sustainability reporting regime for companies in the European Green Deal. See Communication from the Commission on the European Green Deal, COM(2019)640 final.

${ }^{115}$ Alternatively, just transition-related disclosures can be specified in the delegated acts that will be adopted in accordance with the Article 19b of the proposed CSRD to provide for sustainability reporting standards that shall specify the sustainability information that undertakings are to report. The draft standards would be developed by the European Financial Reporting Advisory Group (EFRAG). A recent report prepared by a taskforce established
} 
Just transition disclosures can be important for a couple of reasons. First, they add credibility to the net zero transition plans of companies who need to execute a major transformation. It would be naïve to think that they can smoothly conduct their net zero transition and achieve their targets without addressing social impacts. Therefore, net transition strategies and targets that do not involve social dialogue and engagement with workforce are bound to lose their credibility. ${ }^{116}$ Secondly, they can serve as a kind of nudge for companies to proactively identify and engage with social impacts of their climate action. As noted, this is both beneficial and equitable thing to do. Governments are also actively identifying, tracking and addressing social impacts of climate action. ${ }^{117}$ Private sector solutions from companies whose net zero transition results in such impacts can be reinforcing and arguably in most cases more efficient. ${ }^{118}$ A recent report by Vigeo Eiris, a provider of ESG research and services for investors and public \& private organisations, however, shows that this is mostly lacking. ${ }^{119}$ To understand whether companies are considering the social impacts of their transition, 365 companies generating more than $20 \%$ of their revenue from fossil-fuel related activities were analysed across the dimensions of leadership, ${ }^{120}$ implementation, ${ }^{121}$ and results, ${ }^{122}$ and were found to show mostly

\footnotetext{
by the EFRAG that proposes a roadmap for the development of a comprehensive set of EU sustainability reporting standards notes that "a number of key objectives, policies and regulations are relevant to the work of [the EU standard-setter]", including the EU Green Deal which "addresses[] just transition issues ..." See European Reporting Lab, 'Final Report: Proposals for A Relevant and Dynamic EU Sustainability Reporting StandardSetting' (February 2021), p. 63, available at https://ec.europa.eu/info/publications/210308-efrag-reports en. ${ }^{116}$ In explaining why just transition is important for them, two UK institutional investors state that "[c]ompanies that acknowledge this challenge and plan for a Just Transition, will be more likely to deliver on their commitment to low-carbon growth.” See Royal London Asset Management \& Friends Provident Foundation, 'Expectations For Energy Utilities' Just Transition Strategies' (Nov. 17, 2020), available at https://www.rlam.co.uk/institutional-investors/our-views/2020/expectations-for-energy-utilities-just-transitionstrategies/.

117 There are several government policies, funds and structures that can ease social strains and tensions and achieve a speedy and just transition. See generally, Smith, supra note 53, at 17. For example, governments can recycle their carbon revenues (for example carbon taxes) and form just transition funds to support vulnerable communities. See, e.g., European Commission, 'Employment and Social Developments in Europe', supra note 21, at 185-86. See also the EU's Just Transition Mechanism, https://ec.europa.eu/info/strategy/priorities-20192024/european-green-deal/finance-and-green-deal/just-transition-mechanism_en, last accessed Sept. $27,2021$. Especially, governments can invest in vocational education and training for retraining and reskilling of retrenched workers. ILO, 'The Employment Impact of Climate Change Adaptation', supra note 20, at 27-28.

118 See also Rosenbaum, supra note 29 (noting the funding problems of states' (just transition) programmes and their mixed track record, which create scepticism); Robins, Muller \& Szwarc, supra note 84, at 9 (noting that the efforts by governments are welcome but still need to be scaled up across all countries and sectors, and deepened to produce real-world outcomes.).

119 See for the report, Robins, Brunstig \& Wood, supra note 92, at 17.

${ }^{120}$ It is defined as "[c]ompanies' commitments to minimising the number of lay-offs and framework agreements with employees". See ibid.

${ }^{121}$ It is defined as "[i] nitiatives adopted to mitigate the impacts of restructuring on affected individuals". See $i b i d$.

${ }^{122}$ It is defined as "[s]takeholder feedback on company restructuring processes and related actions, including by trade unions", and avoiding layoffs and promoting alternatives. See ibid.
} 
weak or limited performance. ${ }^{123}$ Thirdly, when standardised, disclosures may better enable institutional investors and other stakeholders to hold companies to account by increasing comparability and measurability. ${ }^{124}$

(c) The Relevance for Institutional Investors and Their Engagement

The frictions between environmental action and social concerns on the path to net zero and just transition also concern institutional investors as shareholders. ${ }^{125}$ As argued above, just transition can be considered as a part of addressing a transition risk and thus climate-related financial risk because "failing to take account of the social dimension will generate pressures to delay, dilute or abandon climate policy" in investee companies, making the shift to a lowcarbon economy less likely. ${ }^{126}$ This makes it relevant for institutional investors who are increasingly concerned with the transition to net zero in investee companies, especially for those that are subject to it as a systematic risk, namely index funds. ${ }^{127}$ Robins, Brunstig \& Wood further point to another systematic risk concern: a transition achieved at high social cost can potentially deepen inequality, harming the sustainability and pace of economic growth which should affect long-term investor returns. ${ }^{128}$ Jeffrey Gordon also argues that a heightening sense of social instability, through the dislocation in careers and life circumstances, and the growing sense of a set-up producing an unacceptable distribution of gains creates a systematic risk in the form of a social stability risk. ${ }^{129}$ When viewed from these lenses, fiduciary duties

\footnotetext{
123 The same report found that North American companies' performance was noticably worse than those from European economies. See ibid.

${ }^{124}$ See also Robins, Muller \& Szwarc, supra note 84, at 33 (noting that "[d]isclosure is essential for investors and other stakeholders to hold companies to account" but currently "[just transition] reporting is bespoke with limited consistency between companies.").

${ }^{125}$ See also Robins \& Rydge, supra note 27, at 41 (stating that "[t]he just transition agenda extends the materiality assessment of climate change to include the social dimension. This means that climate action can no longer be considered by investors as an environmental issue on its own.").

${ }^{126} \mathrm{Ibid}$, at 42 (stating that "[o]ne systemic concern [for investors] is that failing to take account of the social dimension will generate pressures to delay, dilute or abandon climate policy."); Robins, Brunstig \& Wood, supra note 92 , at 11 .

${ }^{127}$ See Krueger, Sautner \& Starks, supra note 32 (finding that "institutional investors believe climate risks have financial implications for their portfolio firms and that these risks, particularly regulatory risks, already have begun to materialize.").

${ }^{128}$ Robins, Brunstig \& Wood, supra note 92, at 11; David Wood, 'Why and How Might Investors Respond to Economic Inequality?' (2016), available at https://www.unpri.org/research/why-and-how-might-investorsrespond-to-economic-inequality/555.article. See also Jonathan D. Ostry et al., Redistribution, Inequality, and Growth, IMF Staff Discussion Note 14/02 (Feb. 2014), available at https://www.imf.org/external/pubs/ft/sdn/2014/sdn1402.pdf; Era Dabla-Norris et al., Causes and Consequences of Income Inequality: A Global Perspective, IMF Staff Discussion Note 15/13 (Jun. 2015), available at https://www.imf.org/external/pubs/ft/sdn/2015/sdn1513.pdf.

${ }^{129}$ See Gordon, supra note 13 , at 30.
} 
(towards ultimate beneficiaries) would arguably require the integration of the risks emanating from the potential clash between environmental and social interests, and just transition into investment and engagement processes. ${ }^{130}$

Therefore, when institutional investors engage with their investee companies on their net zero path, just transition should be a part of it. ${ }^{131}$ With regard to pension funds, workers are already increasingly putting pressure on them in this regard. ${ }^{132}$ Institutional investors' engagement can include 'gauging companies' just transition awareness levels and investigating whether considerations on workforce were included in their climate policies and practices ... [including] potential lay-offs due to climate transition, and strategies to limit the negative impact on employees, such as reorganisation plans and re-training programmes."133

If labour problems and just transition are not deemed (financially) relevant by institutional investors, we may face a scenario where they push for a swift and decisive climate action in investee companies without a consideration of social impacts. ${ }^{134}$ This links to the observation of the alignment between shareholders and environmental interests against those of employees. ${ }^{135}$ On the other hand, 'ESG' funds or 'socially responsible' investors need to take

\footnotetext{
${ }^{130}$ See also Robins, Brunstig \& Wood, supra note 92, at 12 and 16-18 (detailing how institutional investors can integrate just transition into investment strategy); Gordon, supra note 30, at 33 (stating that " $[\mathrm{t}]$ he resulting social stability risk is a cost ... that the sponsors of ... investment vehicles should be mindful of and could well produce support for efforts to mitigate, in the name of improving risk-adjusted returns.").

${ }^{131}$ See, e.g., Smith, supra note 53, at 8 (stating that "[w] hen investors demand that companies have a plan for their emissions to be compatible with a well below $2^{\circ} \mathrm{C}$ world, they should also demand that this plan include the just transition for the company's workforce and communities where the company operates."); Robins \& Rydge, supra note 27, at 42 (detailing "corporate engagement" such as "[i]ncluding just transition factors in investor expectations, requesting disclosure, benchmarking performance, and pressing for improvement.").

${ }^{132}$ Smith, supra note 53, at 9. See also https://www.unpri.org/pri-blog/the-just-transition-how-two-investors-aretackling-its-social-implications/5534.article, last accessed Sept. 29, 2021 (detailing how two labour-related funds took on the just transition agenda).

133 See https://www.unpri.org/pri-blog/incorporating-the-just-transition-in-climate-engagement-an-examplefrom-italy/7973.article, last accessed Sept. 30, 2021. See also Robins, Brunstig \& Wood, supra note 92, at 19-21 (detailing institutional investors' engagement on just transition which includes setting expectations, promoting disclosure, benchmarking company performance, pressing for improvement through dialogue with management and shareholder resolutions, and considering consequences, especially, capital reallocation when companies fail to perform).

${ }^{134}$ See also Zohar Goshen \& Doron Levit, Common Ownership and The Decline of the American Worker, ECGI Law Working Paper No. 584/2021, available at https://papers.ssrn.com/sol3/papers.cfm?abstract id=3832069 (suggesting that a few institutional investors known as common owners shift wealth from labour to capital, exacerbating income inequality); Leo E. Strine, Jr. \& Kirby M. Smith, Toward Fair Gainsharing and a Quality Workplace For Employees: How a Reconceived Compensation Committee Might Help Make Corporations More Responsible Employers and Restore Faith in American Capitalism, 76 The Business Lawyer 31 (2020-2021).

${ }^{135}$ See the text accompanying supra notes 30-32. This is obviously oversimplification. Climate action is in everyone's interest as it preserves the inhabitable planet. It is also in employees' interest when it saves and creates jobs by preventing (or mitigating) extreme weather events and leading to the growth of green sectors. However,
} 
account of just transition as they (claim to) situate their investment and engagement policies around environmental and social concerns. ${ }^{136}$ So far, just transition does not seem to be a mainstream issue for these investors. The UN Principles for Responsible Investing (PRI) Initiative, which boasts thousands of signatories with over US $\$ 100$ trillion worth of assets and promotes ESG issues, ${ }^{137}$ also recently initiated a pledge for investor action on just transition (called "Statement of Investor Commitment to Support a Just Transition on Climate Change"). ${ }^{138}$ The statement is currently only endorsed by 161 investors representing US $\$ 10.2$ trillion in assets. ${ }^{139}$ Limited take-up of the just transition issue by 'ESG' or 'socially responsible' investors can add to the doubts of to what extent these investors 'walk the talk' ${ }^{140}$

Institutional investors' engagement can be particularly beneficial for the achievement of just transition as they can transfer and disseminate successful just transition examples among their investee companies. ${ }^{141}$ Especially, index funds who invest in a market portfolio and amass large stakes can be important for this cross-pollination. ${ }^{142}$ Furthermore, as investors increasingly demand and obtain power over transition plans in companies via the 'say on climate' votes, they can make investee companies address just transition through these votes. ${ }^{143}$

in the short-term, in certain sectors and regions, it can be against the employee interest as the visible resistances demonstrate.

${ }^{136}$ See also Robins, Brunstig \& Wood, supra note 92, at 10 (noting that "the just transition points to the need for [socially responsible] institutional investors to develop a comprehensive response to climate change that connects" environmental, social and governance factors).

137 For the principles of responsible investment, see https://www.unpri.org/pri/what-are-the-principles-forresponsible-investment, last accessed Sept. 23, 2021.

${ }^{138}$ The statement is available at https://www.unpri.org/research/climate-change-and-the-just-transition-a-guidefor-investor-action/3202.article\#Produced_in_collaboration_with, last accessed Sept. 23, 2021.

${ }^{139} \mathrm{Ibid}$. There are also some national initiatives which bring together institutional investors pursuing just transition agenda. See for example French Finance for Tomorrow's taskforce on the just transition (https://www.lse.ac.uk/granthaminstitute/financing-a-just-transition/) and the UK Financing a Just Transition Alliance (https://www.lse.ac.uk/granthaminstitute/financing-a-just-transition/).

${ }^{140}$ See, e.g., Rajna Gibson Brandon et al., Do Responsible Investors Invest Responsibly?, ECGI Finance Working Paper No. 712/2020 (May 2021), https://papers.ssrn.com/sol3/papers.cfm?abstract id=3525530.

141 See, e.g., https://www.unpri.org/pri-blog/incorporating-the-just-transition-in-climate-engagement-anexample-from-italy/7973.article, last accessed Sept. 30, 2021 (giving an example of institutional shareholder engagement in investee companies which aims at, inter alia, "collect[ing] examples of actions undertaken and best practices to benchmark peer companies.").

142 This links to the literature on the stewardship potential of index funds as common or universal owners. See supra note 13. Offset to this potential is the possible anti-competitive effects of common ownership. See, e.g., José Azar, Martin C. Schmalz \& Isabel Tecu, Anticompetitive Effects of Common Ownership, (2018) 73 Journal of Finance 1513.

143 The 'say on climate' initiative requests disclosure by companies of their emission reduction targets and a climate action plan, and ultimately a shareholder vote on this. See https://sayonclimate.org, last accessed Oct. 19, 2021. Although credibility of climate action plans seems important under this initiative, it does not currently feature any just transition-related component, which should add credibility to these plans. 
Some examples exist where institutional investors incorporate the just transition into their engagement policy on an individual or collective basis. ${ }^{144}$ For example, Generali, the Italian insurance company, states in its Group Strategy on Climate Change that "in countries in which the economy and employment depend heavily on the coal sector, Generali will engage the clients and the investees impacted by the Group's restrictions on coal in line with the 'Just Transition' principles." 145 As stated above, pension funds, whether public or private, are also becoming increasingly active in this arena, engaging on just transition with investee companies. ${ }^{146}$ On a collective basis, for instance, Climate Action 100+, an investor-led initiative to ensure sustainability in the world's largest corporate GHG emitters, ${ }^{147}$ will introduce 'just transition' related indicators into its 'Net-Zero Company Benchmark', which is used to assess the performance of focus companies against the initiative's goals, and thus to inform investment and corporate engagement strategies. ${ }^{148}$ SHARE (Shareholder Association for Research \& Education), which provides various investment services to its investor clients, ${ }^{149}$ engages (on behalf of these clients) with investee companies to set and meet ambitious GHG reduction targets while accounting for the impacts on workers and communities. ${ }^{150}$ Another indication that just transition is on the radar of institutional investors

\footnotetext{
${ }^{144}$ In the EU, Article $3 \mathrm{~g}$ of the Shareholders' Rights Directive II requires institutional investors and asset managers (on a comply or explain basis) to develop and disclose an engagement policy (and implementation thereof), describing how they monitor investee companies on relevant matters, including social and environmental impact. See Directive (EU) 2017/828 of the European Parliament and of the Council of 17 May 2017 amending Directive 2007/36/EC as regards the encouragement of long-term shareholder engagement, OJ L 132, 20.5.2017, available at https://eur-lex.europa.eu/legal-content/EN/TXT/?uri=CELEX\%3A32017L0828.

145 See 'Generali Group Strategy on Climate Change: Technical Note' (Update Jun. 2021), available at https://www.generali.com/our-responsibilities/our-commitment-to-the-environment-and-climate. It is also stated that "[t]he aim of this engagement is to accelerate ... [investee companies"] efforts towards the Just Transition with decarbonisation plans that combine climate action with the adoption of protective measures for workers and the local communities.”). See ibid.

${ }^{146}$ See supra note 132.

${ }^{147}$ Currently, it boasts more than 615 investors responsible for over $\$ 55$ trillion in assets. They are engaging companies on improving climate change governance, cutting emissions and strengthening climate-related financial disclosures. See https://www.climateaction100.org/about/, last accessed Oct. 4, 2021.

148 See https://www.climateaction100.org/progress/net-zero-company-benchmark/background/ and https://www.climateaction100.org/news/climate-action-100-calls-for-net-zero-business-strategies-sets-outbenchmark-of-largest-corporate-emitters/, last accessed Oct. 4, 2021. See also Climate Action 100+, '2020 Progress Report' (Dec. 2020), pp. 79-80 (explaining just transition and stating that it is "crucial for companies and investors as it is interlinked with the systemic risk posed by delayed climate action. This contributes to the transition risks faced by companies, including their employees and social or legal licence to operate.").

${ }^{149}$ It provides responsible investment services (shareholder engagement, proxy voting and consulting) to leading Canadian institutional investors with more than $\$ 22$ billion in assets under management. See https://share.ca/about/clients/, last accessed Oct. 4, 2021.

${ }_{150}$ See SHARE, '2021 Engagement Snapshot: Canadian, US \& Global Equities Plan', available at https://share.ca/wp-content/uploads/2021/03/SHARE-engagement-snapshot-2021.pdf.
} 
is the statement of the Investor Agenda, ${ }^{151}$ signed by 587 investors representing over USD \$46 trillion in assets, which calls for "the development of just transition plans for affected workers and communities." 152

There are also cases where high-level commitments of investors translated into action. SSE, a multinational FTSE 100 energy company located in the UK, produced a just transition strategy, following engagement by shareholders led by two UK institutional investors who entered into an ongoing dialogue with management and requested a formal strategy at the annual meeting. ${ }^{153}$ The same coalition of investors has led E.ON, a German listed energy company, to include just transition considerations in its climate-related disclosures. ${ }^{154}$

\section{(d) Green Finance}

Green finance has a big role to play in the decarbonisation and resilience of economy by allocating capital to green assets and climate-resilient activities. To unleash this potential, lawmakers provide increasingly complex sustainability regime for financial market participants, mainly depending on disclosure requirements in order to bring these market players in line with ultimate investors' preferences. ${ }^{155}$ Regulators also tighten their grip on these financial players to prevent greenwashing. ${ }^{156}$

Green finance may also play a significant role in just transition by integrating the impacts on affected workers and communities - social factors - into capital allocation as well as by

\footnotetext{
${ }^{151}$ It is formed by major groups working with investors to provide "a common leadership agenda on the climate crisis that is unifying, comprehensive, and focused on accelerating investor action for a net-zero emissions economy." See https://theinvestoragenda.org/about-the-agenda/, last accessed Oct. 4, 2021.

${ }^{152}$ See The Investor Agenda, '2021 Global Investor Statement to Governments on the Climate Crisis', p. 2, available at https://theinvestoragenda.org/focus-areas/policy-advocacy-2021-gis/.

153 See Robins, Muller \& Szwarc, supra note 84, at 26. See also https://www.friendsprovidentfoundation.org/news/applause-for-sses-sector-first-just-transition-strategy/, last accessed Oct. 7, 2021.

${ }^{154}$ See E.ON, 'On Course For Net Zero: Supporting Paper for E.ON's Decarbonization Strategy and Climaterelated Disclosures' (Mar. 2021), pp. 17-20, available at https://www.eon.com/content/dam/eon/eon-com/eoncom-assets/documents/sustainability/en/tcfd/EON_2021_On_course_for_net_zero.pdf.

${ }^{155}$ See, e.g., Tobias Tröger \& Sebastian Steuer, The Role of Disclosure in Green Finance, ECGI Law Working Paper No. 604/2021, available at https://papers.ssrn.com/sol3/papers.cfm?abstract_id=3908617.

${ }^{156}$ For example, regulators on both sides of the Atlantic are currently probing into allegations against DWS, the asset management arm of Deutsche Bank, for unjustified claims about sustainability practices. See Attracta Mooney \& Chris Flood, 'DWS probes spark fears of greenwashing claims across investment industry' (Aug. 31, 2021), Financial Times, https://www.ft.com/content/a3d6a8d1-0800-41c9-ab92-c0d9fce1f6e1, last accessed Oct. 8,2021 (suggesting that "regulatory investigations into DWS are unlikely to be a one-off.").
} 
targeting investments that contribute to achieving the just transition. ${ }^{157}$ To this end, for capital markets, just transition factors can be included into stock/bond selection, index design and benchmarking. ${ }^{158}$ To accelerate the integration of just transition into capital allocation, providers of investment research, rating and consulting services can help investors with necessary insights into the risks and opportunities around just transition. ${ }^{159}$ Banks may also integrate just transition factors into their (green or ESG) loans, and develop lending strategies for exposed regions. ${ }^{160}$

Growing in size and sophistication, green bonds currently contribute to financing assets needed for the low-carbon transition. ${ }^{161}$ Such bonds are now extended to include social and other sustainability factors under the brand of 'sustainability bonds' ${ }^{162}$ These bonds can also make a significant contribution to the just transition. For example, companies, using the proceeds to invest in green assets and operations, can simultaneously create jobs for workers bearing the brunt of net zero transition by employing them directly or after reskilling and retraining (by using part of the proceeds for this purpose). ${ }^{163}$

Is the regulatory framework conducive to green finance playing a role also in the just transition? In the EU, the Sustainable Finance Disclosure Regulation ('SFDR') already covers the 'social'

\footnotetext{
${ }^{157}$ For more detail on capital allocation for the just transition across asset classes, see Robins, Brunstig \& Wood, supra note 92 , at 22 .

158 Ibid.

${ }^{159}$ Ibid. Abovementioned examples can be useful in this regard. See the text accompanying supra notes 147-148 (Climate Alliance 100+ providing Net-Zero Company Benchmark with just transition-related indicators) and 119122 (Vigeo Eiris evaluating major corporate GHG emitters' performance on just transition). In addition, the World Benchmarking Alliance has developed a framework for assessing the performance of 450 high emitting companies on just transition. See https://www.worldbenchmarkingalliance.org/research/just-transition-launch-of-themethodology/, last accessed Oct. 6, 2021.

${ }^{160}$ Robins, Brunstig \& Wood, supra note 92, at 22. See also Nick Robins, Sophia Tickell, William Irwin \& Andrew Sudmant, 'Financing Climate Action with Positive Social Impact: How Banking Can Support A Just Transition in the UK' (Jul. 2020), available at https://www.lse.ac.uk/granthaminstitute/publication/financingclimate-action-with-positive-social-impact-how-banking-can-support-a-just-transition-in-the-uk/.

161 See, e.g., Caroline Flammer, 'Green Bonds: Effectiveness and Implications for Public Policy', in Environmental and Energy Policy and the Economy, Matthew J. Kotchen, Tatyana Deryugina \& James H. Stock (eds.), 2020 (vol. 1), pp. 95-128; Serena Fatica \& Roberto Panzica, Green Bonds As A Tool Against Climate Change?, (2021) 30 Business Strategy and the Environment 2688.

162 See, e.g., https://www.icmagroup.org/sustainable-finance/the-principles-guidelines-andhandbooks/sustainability-bond-guidelines-sbg/, last accessed Oct. 2, 2021.

${ }^{163}$ In its green sovereign bond programme, the UK government, for example, will report on the social co-benefits in addition to the environmental impact of the proceeds invested. See Her Majesty's Treasury, 'UK Government Green Financing Framework' (Jun. 2021), p. https://assets.publishing.service.gov.uk/government/uploads/system/uploads/attachment_data/file/1002578/2021 0630_UK Government_Green_Financing Framework.pdf.
} 
aspect of the sustainability. ${ }^{164}$ For example, if investments are made in companies where there can be frictions between labour and environmental interests in the net zero transition, and the lack of just transition plans amplifies the potential transition risk resulting therefrom, there will arise a "sustainability risk" 165 which produces a few disclosure requirements for "financial market participants' and 'financial advisers'. ${ }^{166}$ If ultimate investors (equipped with this information) are concerned with such a sustainability risk, ${ }^{167}$ investment intermediaries will need to take action: exit (in other words, divestment which is not possible for every investor and does not really address the issue) or voice (in other words, engagement with investee companies to ameliorate this risk). Furthermore, if financial products offered make investments related to just transition (for example, assets providing decent job opportunities for retrenched workers after retraining and reskilling), they promote 'social characteristics' or have 'sustainable investment' as their objective, ${ }^{168}$ which triggers further disclosure. ${ }^{169}$ The latter should help these products attract capital, for example, by providing more credible (and standardised) information. ${ }^{170}$

\footnotetext{
${ }^{164}$ See the definitions of 'sustainable investment', 'sustainability risk' and 'sustainability factors' under Article 2 of Regulation (EU) 2019/2088 of the European Parliament and of the Council of 27 November 2019 on sustainability-related disclosures in the financial services sector, OJ L 317, 9.12.2019, available at https://eurlex.europa.eu/legal-content/EN/TXT/?uri=celex\%3A32019R2088 (henceforth SFDR).

${ }^{165}$ Because there will be "[a social] ... event or condition that, if it occurs, could cause an actual or a potential material negative impact on the value of the investment." See ibid.

${ }^{166}$ For the definitions of 'financial market participant' and 'financial adviser' see Article 2. Under article 3, financial market participants or financial advisers are required to publish on their websites information about their policies on the integration of sustainability risks in their investment decision-making process. Under article 6, they are required to include in pre-contractual disclosures, (a) the manner in which sustainability risks are integrated into their investment decisions; and (b) the results of the assessment of the likely impacts of sustainability risks on the returns of the financial products they make available. If they deem sustainability risks not to be relevant, they need to disclose a clear and concise explanation of the reasons therefor. See $i b i d$.

${ }^{167} \mathrm{An}$ important problem is that investor preferences may not be reflected in their actual investment behaviour. See, e.g., Veerle Colaert, 'Integrating Sustainable Finance into the MIFID II and IDD Investor Protection Frameworks', in Sustainable Finance in Europe: Corporate Governance, Financial Stability and Financial Markets, Danny Busch, Guido Ferrarini \& Seraina Grünewald (eds.), 2021, pp. 445-475.

${ }^{168}$ Under article 2, sustainable investment is defined as ".. an investment in an economic activity that contributes to a social objective, in particular an investment that contributes to tackling inequality or that fosters social cohesion, social integration and labour relations, or an investment in human capital or economically or socially disadvantaged communities ..." Social characteristics are not defined by the regulation. See SFDR, supra note 164.

${ }^{169}$ See articles 8, 9, 10 of SFDR, supra note 164 (detailing the disclosures to be made in pre-contractual documents, websites and annual reports)

${ }^{170}$ See, e.g., Tröger \& Steuer, supra note 155, at 37-45 (on the question of why such disclosures should be mandatory).
} 
The arguably most ambitious part of the EU's Sustainable Finance Package, the Taxonomy Regulation, currently concerns only environmental sustainability. ${ }^{171}$ But, the European Commission is considering extending it to social factors, developing a social taxonomy. A subgroup of the Platform on Sustainable Finance, the advisory body which assists the Commission in developing its sustainable finance policies, particularly the further development of the EU taxonomy, ${ }^{172}$ works on extending it to social objectives. ${ }^{173}$ A recent draft report by this group on the merits and possible structure of a social taxonomy counts " $[\mathrm{t}]$ he need for investment in a just transition" among the merits of the social dimension, ${ }^{174}$ and recommends "ensuring decent work" as one of the objectives in a future social taxonomy. ${ }^{175}$

Furthermore, a recent Communication from the European Commission on the 'Strategy for Financing the Transition to a Sustainable Economy' (also known as 'Renewed Sustainable Finance Strategy') notes, under the heading of 'supporting credible social investments', that "[t]he recovery from the pandemic has highlighted the need for a just transition that supports workers and their communities affected by the transitioning of economic activities."176 This has apparently prompted the Commission to take further action, which states that "[s]ustainable finance disclosure requirements for financial market participants already include certain social factors, but further steps are needed", especially with regard to the SFDR and social taxonomy. ${ }^{177}$

\footnotetext{
${ }^{171}$ See Regulation (EU) 2020/852 of the European Parliament and of the Council of 18 June 2020 on the establishment of a framework to facilitate sustainable investment, and amending Regulation (EU) 2019/2088, OJ L 198, 22.6.2020, available at https://eur-lex.europa.eu/legal-content/EN/TXT/?uri=celex:32020R0852.

172 On this Platform, see https://ec.europa.eu/info/business-economy-euro/banking-and-finance/sustainablefinance/overview-sustainable-finance/platform-sustainable-finance_en, last accessed Oct. 4, 2021.

173 Ibid.

${ }^{174}$ See Platform on Sustainable Finance, 'Draft Report by Subgroup 4: Social Taxonomy' (Jul. 2021), pp. 11 12 , available

https://ec.europa.eu/info/sites/default/files/business_economy euro/banking and finance/documents/sf-draftreport-social-taxonomy-july2021_en.pdf (stating that "[t]he transition to a sustainable, zero net emissions, climate-resilient economy requires crucial changes in sectors such as mining, manufacturing, agriculture and forestry. These changes will have an impact - not necessarily positive - on the lives of workers in these sectors and their communities ... The term 'just transition' is used to describe the need to avoid unilaterally imposing the burden of these inevitable but necessary changes on workers and disadvantaged communities.").

${ }^{175}$ See ibid., at 34. Substantial contribution to this objective would include "employment generation for certain groups of people as it also relates to the 'just transition'." Ibid., at 37.

176 See COMMUNICATION FROM THE COMMISSION TO THE EUROPEAN PARLIAMENT, THE COUNCIL, THE EUROPEAN ECONOMIC AND SOCIAL COMMITTEE AND THE COMMITTEE OF THE REGIONS, Strategy for Financing the Transition to a Sustainable Economy, COM/2021/390 final (Jul. 6, 2021), p. 9, available at https://eur-lex.europa.eu/legal-content/EN/TXT/?uri=CELEX:52021DC0390. It further states that "[t]he steep increase in social bond issuance shows that investors are increasingly looking for investment opportunities with positive social outcomes and promoting human rights." Ibid.

${ }^{177} \mathrm{Ibid}$, at 9-10.
} 


\section{Conclusion}

Climate change is currently one of the biggest challenges of our world, which requires a swift and decisive action. As main contributors to climate change, companies need to be part of the solution by transitioning to net zero by 2050 . As a result, the incorporation of sustainability or ESG factors into company operations has become a paramount concern on the part of policymakers, regulators, and various stakeholders such as investors. However, as the 'environmental' aspect of sustainability or ESG agenda comes to the forefront, its potential clash with the social aspect or interests should be noted. ${ }^{178}$ Especially, in the context of climate change, the net zero transition will not be inclusive by default. In certain sectors and regions, there can be significant negative effects for the workforce and communities.

If not managed well, these effects may lead to a slowed-down or hampered net zero transition process in companies, as already seen on the country level. Or a transition without addressing social impacts may result in an unbalanced distribution of costs and benefits of climate action, harming the social fabric.

As a concept, 'just transition' aims to tackle social impacts while undertaking the urgent and necessary net zero transition. If conducted well, it may help shift to a low-carbon economy at the scale and pace required to avoid the catastrophic climate events (by increasing its acceptability) and make this shift more equitable. ${ }^{179}$ Companies have also a big role to play in a just transition. They should gauge the impact of their policies on their workforce and the communities where they operate, enter a social dialogue with them, and actively address negative consequences, for example, by reskilling and retraining their employees, easing their move to other locations, or to (early) retirement. Some utilities companies already acted in this regard with (varying) success, showing that a just transition is possible.

The (potential) clash between the workforce and environmental action and just transition as a way of addressing it have numerous implications for sustainable corporate governance and finance. First, how directors' duties are shaped may have different repercussions for how

\footnotetext{
${ }^{178}$ See also Robins, Muller \& Szwarc, supra note 84, at 10 (“'[u]ntil recently, most investors have managed climate change primarily as an environmental driver of risk, return and responsibility. Yet, with the structural economic and social change required for the net-zero transition, a rounded perspective is needed to move away from economic, social and governance (ESG) silos that look at the 'E', 'S', and 'G' issues separately.').

${ }^{179}$ Robins, Brunstig \& Wood, supra note 92, at 28.
} 
companies approach this problem and its solution, but ultimately does not seem to play a significant role. Using key sustainability performance indicators in executive remuneration seems promising for the environmental performance of the firm but should also consider social aspects of decarbonising company operations. Second, just transition-related disclosure should be a part of the sustainability disclosures (mandatory or voluntary regimes). Most importantly, the potential friction between employees' interests and climate action may render the latter slower or less likely, which makes it a part of the transition risk (a climate-related financial risk). And the way to ameliorate this risk is the concept of just transition. These considerations make pertinent disclosures necessary. Third, the same considerations make just transition relevant for institutional investors which otherwise face increased systematic risk (in terms of transition risk and increased inequality/social instability). Their engagement can be particularly helpful in spurring and disseminating the needed action for just transition in companies. ${ }^{180}$ Lastly, green finance has a big role to play not only in assisting the net zero transition in companies but also in making it just. Banks and capital markets, especially sustainable bonds, can make a significant contribution to just transition in a regulatory environment conducive to it.

\footnotetext{
${ }^{180} \mathrm{Ibid}$. , at 14 (“... there is now a concern that the failure to effectively manage the social dimension of the climate transition could generate a new set of investment risks in terms of political instability, depressed economic activity and insufficient progress in the delivery of climate targets. What the just transition approach does is anticipate these risks and deliver strategies that help to realise a strong social dimension to climate action.”).
} 


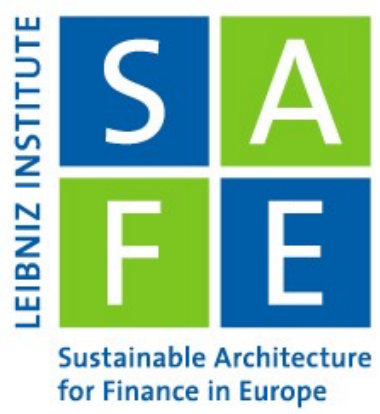

\section{Recent Issues}

No. 324 Massimiliano Caporina, Michele Costola

No. 323 Alexandre Corhay, Thilo Kind, Howard Kung, Gonzalo Morales

No. 322 Gianluca Anese, Marco Corazza, Michele Costola, Loriana Pelizzon

No. 321 Ignazio Angeloni, Johannes Kasinger, Chantawit Tantasith

No. 320 Sebastian Steuer, Tobias H. Tröger

No. 319 Erik Theissen, Christian Westheide

No. 318 Kevin Bauer, Michael Kosfeld, Ferdinand von Siemens

No. 317 Volker Flögel, Christian Schlag, Claudia Zunft

No. 316 Christian Mücke, Loriana Pelizzon, Vincenzo Pezone, Anjan Thako

No. 315 Kevin Bauer, Moritz von Zahn, Oliver Hinz

No. 314 Farshid Abdi, Mila Getmansky Sherman, Emily Kormanyos, Loriana Pelizzon, Zorka Simon

No. 313 Kevin Bauer, Andrej Gill

No. 312 Can Gao lan Martin

No. 311 Wenhui Li, Christian Wilde

No. 310 Carmelo Latino, Loriana Pelizzon, Aleksandra Rzeźnik
Time-Varying Granger Causality Tests for Applications in Global Crude Oil Markets: A Study on the DCC-MGARCH Hong Test

Discount Rates, Debt Maturity, and the Fiscal Theory

Impact of Public News Sentiment on Stock Market Index Return and Volatility

The Geography of Banks in the United States (1990-2020)

The Role of Disclosure in Green Finance

Call of Duty: Designated Market Maker Participation in Call Auctions

Incentives, Self-Selection, and Coordination of Motivated Agents for the Production of Social Goods

Momentum-Managed Equity Factors

The Carrot and the Stick: Bank Bailouts and the Disciplining Role of Board Appointments

Expl(AI)ned: The Impact of Explainable Artificial Intelligence on Cognitive Processes

A Modern Take on Market Efficiency: The Impact of Trump's Tweets on Financial Markets

Mirror, Mirror on the Wall:

Machine Predictions and Self-Fulfilling Prophecies

Volatility, Valuation Ratios, and Bubbles: An Empirical Measure of Market Sentiment

Separating the Effects of Beliefs and Attitudes on Pricing under Ambiguity

The Power of ESG Ratings on Stock Markets 